NBER WORKING PAPER SERIES

\title{
EXCHANGE RATE REGIME DURABILITY AND PERFORMANCE IN DEVELOPING VERSUS ADVANCED ECONOMIES
}

\author{
Aasim Husain \\ Aska Mody \\ Kenneth S. Rogoff \\ Working Paper 10673 \\ http://www.nber.org/papers/w10673 \\ NATIONAL BUREAU OF ECONOMIC RESEARCH \\ 1050 Massachusetts Avenue \\ Cambridge, MA 02138
}

August 2004

This paper was prepared for the Carnegie-Rochester Conference (April 2004) and will be published in the Journal of Monetary Economics, January 2005, Volume 52:1. It draws on the authors' earlier work with Robin Brooks and Nienke Oomes (Rogoff et al, 2004), to which contributions from Andrew Berg, Grace Juhn, Paolo Mauro, and Antonio Spilimbergo are also gratefully acknowledged. The authors are indebted to Rex Ghosh for providing his dataset and to Young Kim and Eisuke Okada for valuable research assistance. For many helpful comments, we would like to thank, without implicating, David Backus, Tam Bayoumi, Michael Bordo, Agustín Carstens, Barry Eichengreen, Inci Otker-Robe, Charles Plosser, Jacques Polak, Carmen Reinhart, David Robinson, Miguel Savastano, Federico Sturzenegger, Lars Svensson, participants at the Carnegie-Rochester Conference, and an anonymous referee. The views expressed in this paper are of those of the authors and not necessarily those of the International Monetary Fund.The views expressed herein are those of the author(s) and not necessarily those of the National Bureau of Economic Research.

C2004 by Aasim Husain, Ashoka Mody, and Kenneth S. Rogoff. All rights reserved. Short sections of text, not to exceed two paragraphs, may be quoted without explicit permission provided that full credit, including (C) notice, is given to the source. 
Exchange Rate Regime Durability and Performance in Developing Versus Advanced Economies Aasim Husain, Ashoka Mody, and Kenneth S. Rogoff

NBER Working Paper No. 10673

August 2004

JEL No. Aasim Husain, Ashoka Mody, and Kenneth S. Rogoff

\begin{abstract}
Drawing on new data and advances in exchange rate regimes' classification, we find that countries appear to benefit by having increasingly flexible exchange rate systems as they become richer and more financially developed. For developing countries with little exposure to international capital markets, pegs are notable for their durability and relatively low inflation. In contrast, for advanced economies, floats are distinctly more durable and also appear to be associated with higher growth. For emerging markets, our results parallel the Baxter and Stockman classic exchange regime neutrality result, though pegs are the least durable and expose countries to higher risk of crisis.
\end{abstract}

Aasim M. Husain

Research Department

International Monetary Fund

$70019^{\text {th }}$ Street, NW

Washington, DC 20431

Ashoka Mody

Research Department

International Monetary Fund

$70019^{\text {th }}$ Street, NW

Washington, DC 20431

Kenneth S. Rogoff

Department of Economics

Harvard University

Littauer Center

Cambridge, MA 02138

and NBER

krogoff@harvard.edu 


\section{INTRODUCTION}

This paper offers a distinct new twist to the existing academic and policy literature on the durability and performance of alternative exchange rate regimes by drawing on new data and on a new de facto approach to classifying exchange rate regimes (see Reinhart and Rogoff, 2004). ${ }^{1}$ Although there are many nuances, overall our results suggest that for relatively poor countries with little access to international capital markets, pegged exchange rate regimes work surprisingly well, delivering both relatively low inflation and relatively high exchange rate regime durability. This finding is in contrast to the growing conventional policy wisdom that pegs are universally unstable and crisis prone. However, we also find that as countries become richer and more financially developed, they benefit by moving to more flexible exchange rate systems. Indeed, for advanced economies, flexible exchange rate systems are remarkably durable and (controlling for other factors) yield somewhat higher growth without higher inflation. For emerging markets, the exchange regime does not appear to have a systematic effect on inflation or growth, although — in line with conventional wisdom — pegs are distinctly more vulnerable to banking and exchange rate crises.

Our results also indicate that, in general, exchange rate regimes have been steadily becoming less durable since the mid-1970s, with emerging markets experiencing the most instability. An important exception, however, is advanced economies, for which durability

\footnotetext{
${ }^{1}$ The distinction between stated (de jure) and actual (de facto) policies has received considerable prominence recently, with contributions from Levy-Yeyati and Sturzenegger $(2002,2003)$ and Reinhart and Rogoff (2004). The IMF itself now publishes regime descriptions that lean towards the de facto characterization. However, de facto measures vary considerably, depending on the methodology used to assess regimes.
} 
has increased, particularly for flexible rate systems. We also observe a broad trend towards exchange rate regimes with intermediate levels of inflexibility (in contrast to the once fashionable bi-polar hypothesis). Extrapolating out our estimated exchange rate regime transition matrices suggests that pegs, which today account for roughly $40 \%$ of all developing country and emerging market exchange rates, will account for only $25 \%$ of all regimes in 2020, with intermediate regimes taking up the slack.

In the next section, we discuss alternatives to regime classification and then present evidence on regime durability for all countries and also for developing and emerging market economies. We turn to the evidence on regime performance-evaluating performance in terms of inflation, growth, and crisis outcomes, and differentiating once again between developing, emerging, and advanced economies. It is important to note that whereas one's perspective on regime durability can be quite sensitive to the particular classification system chosen, our results on regime performance are much less sensitive. Rather, the key factor underpinning our results is our three-way grouping of countries into developing, emerging, and advanced. The final section concludes.

\section{Regime Classification ANd DURABILITY}

Any assessment of the impact of a country's exchange rate regime on its economic performance must first settle on definitions for alternative regimes. This section makes a case for using Reinhart and Rogoff's (2004) "Natural” classification for characterizing true regimes. It then uses the Natural classification to document the main features of regime evolution and durability across countries, differentiating between groups of countries with 
markedly different levels of development and relationship with international capital markets.

Longevity of regimes may be suggestive of stronger sustainability and superior performance.

\subsection{Regime classification}

The early debate on exchange rate regimes largely focused on the benefits and costs associated with fixed versus flexible regimes. In their analysis, Baxter and Stockman (1989) essentially viewed regimes in industrial countries as either fixed or floating. Subsequent analysis, and indeed Baxter and Stockman's own comments on developing countries, increasingly recognized that countries' regimes are often neither completely fixed nor fully flexible. As Williamson (2000) has argued, such "intermediate" regimes could, in principle, allow countries to reap the benefits of fixed and flexible regimes without incurring some of their costs. Others, however, have been more skeptical. According to the "bipolar" view, intermediate regimes are unsustainable over the long run, forcing countries - at least those with open capital accounts - to choose between freely floating exchange rates or monetary union with another currency. ${ }^{2}$

Beyond the level of disaggregation of regimes is the system by which they are classified. Until the late 1990s, the only comprehensive classification available was the one

\footnotetext{
${ }^{2}$ For example, Eichengreen (1994) argued that countries "will be forced to choose between floating exchange rates on the one hand and monetary unification on the other." More recently, Summers (2000) has argued that, for economies with access to international capital markets, "the choice of appropriate exchange rate regime... increasingly means a move away from the middle ground of pegged but adjustable fixed exchange rates towards the two corner regimes." Fischer (2001) even presented evidence to support his view that "[I]n the last decade, there has been a hollowing out of the middle of the distribution of exchange rate regimes in a bipolar direction, with the share of both hard pegs and floating gaining at the expense of soft pegs.”
} 
produced annually by the IMF, on the basis of countries' announced (or de jure) regimes. In practice, however, exchange rate regimes often differed from those that had been declared. For example, devaluations were common in some "pegged" regimes, while many floats moved within tight bands. Consequently, the de jure classification inaccurately characterized the de facto regime. Recognizing this problem, the IMF itself moved to a new de facto classification from 1999 that combined information on the exchange rate and monetary policy framework and policy intentions with data on actual exchange rate and reserves movements. ${ }^{3}$ Other de facto regime classification systems have also been proposed, including those by Ghosh et al. (1997), who classified regimes on a de facto basis using information on actual exchange rate movements, and Ghosh, Gulde, and Wolf (2003), who reexamined the evidence on macroeconomic performance under alternative de jure regimes by checking the robustness of their results against a hybrid de jure/de facto classification. ${ }^{4}$ Another classification system, devised by Levy-Yeyati and Sturzenegger (2003), discarded the de jure classification altogether and instead employed purely statistical techniques to exchange rate and reserves data to determine the de facto flexibility of exchange rate regimes. ${ }^{5}$

\footnotetext{
${ }^{3}$ See IMF (1999), Chapter IV, for details. The IMF de facto classification is, in effect, a hybrid classification system that combines data on actual flexibility with information on the policy framework. Using historical data and information on countries' exchange arrangements, Bubula and Ötker-Robe (2002) have put together a database containing IMF de facto classifications for virtually all IMF member countries going back to 1990 .

${ }^{4}$ The hybrid classification — referred to as the "consensus" classification by Ghosh, Gulde, and Wolf-discards observations for which the de jure classification does not match a de facto one based on actual exchange rate movements. Effectively, this procedure narrows the sample by 35 percent over the 1970-99 period.

${ }^{5}$ The Levy-Yeyati-Sturzenegger dataset, which goes back to 1974, attempts to classify —on an annual basis - about 180 countries in terms of actual flexibility. However, about one third
} 
In setting forth their comprehensive "Natural" classification scheme, Reinhart and Rogoff (2004) note that the other de facto classification systems, while more appropriate than the de jure classification, continue to misclassify regimes because they do not take into account several key features in regimes' actual operation. Their Natural classification seeks to address the potential misclassification by separating episodes of macroeconomic instability that are characterized by very high inflation rates, often reflected in high and frequent exchange rate depreciation, into a "freely falling" category. Classification of such episodes as floating, intermediate, or pegged is problematic, since the macroeconomic disturbances could be incorrectly attributed to the exchange rate regime. Moreover, where a parallel exchange rate deviates substantially from the official rate, movements in the parallel rate-which offers a more realistic barometer of the underlying monetary stance, rather than the official rate - are used to gauge the flexibility of the regime. ${ }^{6}$ Lastly, to avoid recording a large number of regime shifts following exchange rate and reserves movements that are, in fact, related to transient economic or political shocks but do not involve a change in the underlying regime, the Natural classification employs a rolling five-year horizon to measure the true flexibility of the regime. This helps distinguish between longer-term "regimes" and shorter-term "spells" within a regime, such as the widening of a horizontal band or a onetime devaluation followed by a re-peg.

of the observations in their sample cannot be classified by their algorithm because of missing data or because the exchange rate was pegged to an undisclosed basket.

${ }^{6}$ Dual or multiple exchange rates were prevalent in the early $1970 \mathrm{~s}$, accounting for about one half of all regimes (Reinhart and Rogoff, 2004). In recent years, however, the proportion of countries with substantial parallel markets has diminished to less than 10 percent. 
Comparison of regime classifications across the de jure and Natural classifications highlights the pitfalls of using the de jure classification to draw inferences about regime durability or performance. As Figure 1 illustrates, only about one half of the observationswhere each observation corresponds to a given country's regime in a particular year-were classified the same way by both the de jure and the Natural classifications. Among so-called "free floats," only 20 percent in fact operated as true floats, while 60 percent were either intermediate or pegged regimes and another 20 percent had freely falling currencies. Hence, the wide divergence between the regimes countries say they have and those they actually operate potentially suggests considerable variation also in the relationship between stated and actual regimes, on the one hand, and economic performance, on the other.

Viewed through the Natural classification, the global distribution of exchange rate regimes has evolved relatively gradually. Although the collapse of the Bretton Woods system saw a sharp decline in the proportion of pegged regimes, forming the basis of the Baxter and Stockman (1989) analysis, the change fell well short of a dichotomous shift from a world of pegs to one of floats (Figure 2). A significant proportion of non-pegged regimes were in operation during the Bretton Woods era, and pegged regimes have by no means disappeared in the post-Bretton Woods period. Rather, they continue to account for a sizable portion of all regimes, and their prevalence has actually increased over the past decade. Also, while true free floats have been around only since the early 1970s, they remain relatively rare.

Since the interaction of the exchange rate regime with the performance of the economy is likely to be shaped by the economy's institutional and financial maturity and its openness to capital flows, it is helpful to distinguish between different types of countries in order to assess this interaction. In particular, countries with a mature economic and financial 
structure are likely to respond differently to a particular type of exchange rate arrangement than are developing countries. Similarly, among developing countries, those that are exposed to large capital flows may well perform differently under certain regimes than countries that are relatively closed to flows of foreign capital. For the purposes of this analysis, countries are divided into three groups—-advanced, emerging market, and developing. Advanced countries are selected using the World Bank definition for upper income countries, following Ghosh, Gulde, and Wolf (2003). In dividing the remainder, the analytical distinction of relevance is their degree of exposure to international capital markets. The emerging markets group is defined using the Morgan Stanley Capital International (MSCI) classification, which designates a country as an emerging market according to a number of factors related to international capital market access-GDP per capita, local government regulations, perceived investment risk, foreign ownership limits and capital controls, and other factors. ${ }^{7}$ All remaining countries are designated "developing." The appendix provides a list of countries in each group.

Division of the world into these three groups yields additional insights into the distribution and evolution of exchange rate regimes:

- $\quad$ As Figure 2 shows, the collapse of Bretton Woods indeed marked a major change in the distribution of regimes among advanced economies. During the 1980s and 1990s,

\footnotetext{
${ }^{7}$ To distinguish between emerging and developing economies, exposure to international capital can be determined either in a de jure sense (the extent of formal capital controls in place) or in a de facto sense (the actual exposure a country faces). In the spirit of this paper, a de facto definition was appropriate, an approach also followed by Prasad, Rogoff, Wei, and Kose (2003). See http://www.msci.com/equity/index.html for more information on the MSCI classification of emerging markets.
} 
however, pegs regained popularity, although free floats and intermediate regimes remained in place in about one half of all advanced economies at the turn of the century.

- $\quad$ By contrast, the Bretton Woods collapse was much less of a watershed event for emerging markets and developing countries, at least as far as their exchange rate regimes were concerned. Both groups of countries saw a gradual decline in the share of pegs in all regimes during the 1970s and 1980s, but not an abrupt shift.

- The prediction of the bipolar hypothesis - that intermediate regimes would tend to give way to regimes at either polar end of flexibility—is not evident in the data, especially among the emerging markets group, where bipolar proponents had considered the hypothesis most applicable. Rather, intermediate regimes have constituted the bulk of all regimes in emerging markets for the past two decades, and very few emerging markets had moved to true hard pegs or free floats even by 2001 .

\subsection{Regime durability}

If the evolution of exchange rate regimes has varied across different country groups, then the durability of alternative regimes has presumably also varied significantly. Figure 3 illustrates the number of exchange rate regime transitions in each country group since the 1940s. As can be expected, major global and regional events have influenced the frequency of transitions. The Bretton Woods system collapsed on account of the pressures built up in a relatively rigid system of exchange rate regimes and was followed by a sharp increase in transitions to more flexible arrangements in advanced economies and a fair number of developing countries. The debt crisis of the 1980s and the transformation of the economies of 
central and eastern Europe and the Former Soviet Union in the early 1990s were also accompanied by a relatively high frequency of emerging market and developing country regime transitions, especially into and subsequently out of the freely falling category. In the latter half of the 1990s, as several large emerging markets faced external financing crises, the frequency of exchange rate regime transitions among the emerging market group rose once again. And in 1999, a major transition occurred among advanced economies with the adoption of monetary union in the euro area.

Once transitions related to these global events and into and out of the freely falling category are distinguished, it turns out the frequency of changes in countries' exchange rate regimes today is remarkably similar to fifty years ago. As Figure 2 illustrates, the average number of countries transitioning to a different regime (excluding transitions into and out of the freely falling category) in any given year since the collapse of the Bretton Woods system was about the same as during the Bretton Woods period. And in the 1990s, fewer low income developing countries transitioned toward more flexible regimes than to less flexible regimes, although the bulk of the transitions for this group were into and out of the freely falling category.

Calculations of regime durability reveal interesting variation across country groups, across regime types, and over time (Table 1). The durability of regimes, measured as the average number of years a country maintains its Natural classification regime before transitioning to another regime or to a freely falling episode, has been somewhat shorter in emerging markets (about 10 years) than in advanced economies (14 years) and developing countries (16 years). Since 1975, regime durability in emerging markets has declined further to about $81 / 2$ years on average, possibly because of their increased exposure to volatile 
international capital flows and their inability to efficiently intermediate them. Advanced economies, on the other hand, have seen their exchange rate regimes become more durable since the mid-1970s, as the build up of imbalances of the sort that existed toward the end of the Bretton Woods period have largely been avoided.

Contrary to the notion that pegs are less durable than other regimes because they require increased macroeconomic policy discipline, Table 1 suggests that pegs have, on average, been more durable than other regimes, both during the Bretton-Woods era and afterward. ${ }^{8}$ Among emerging markets, however, pegs have been less durable than other regimes. Since 1975, pegged regimes in emerging markets have lasted, on average, less than $81 / 2$ years, while the average intermediate and floating regime has persisted for $161 / 2$ and 11 years, respectively. This is consistent with the view that exposure to foreign capital flows makes it is more difficult to sustain a peg if the domestic financial system is not sufficiently mature to efficiently intermediate those flows. While pegs have been much more durable in developing countries (both in relation to emerging markets and compared to other regimes in developing countries), their longevity has declined quite sharply since 1975, perhaps suggesting that sustaining pegs has become more difficult even in developing countries with limited exposure to international capital markets.

\footnotetext{
${ }^{8}$ This conclusion contrasts with the results obtained by Klein and Marion (1997), Eichengreen and others (1998), and Duttagupta and Ötker-Robe (2003), among others, who find the longevity of pegs to be much shorter. This is mainly because the Natural classification attempts to identify longer-term regimes rather than short-term "spells," which are analyzed in the other studies. Masson (2001), on the other hand, obtains very similar results to ours for regime transition rates and duration using the Ghosh et al. (1997) classification.
} 
The duration of intermediate regimes in advanced economies has been shorter than that of other regimes, especially since 1975 . This may be because they have been used as a temporary device during a longer-term transition from one polar extreme of flexibility to the other, as in the euro area in the 1980s and 1990s. In emerging markets, by contrast, intermediate regimes have tended to persist for longer — and have, perhaps, been easier to sustain - than other regimes.

Free floats have proven extremely durable in advanced countries, but fragile in developing countries and emerging markets. Advanced economies that have adopted freely floating exchange rates have, almost without exception, stuck with them, possibly because they have conferred important advantages. Free floats in emerging markets, on the other hand, have been extremely rare, and their low average durability (relative to advanced country floats) suggests a lingering temptation to "manage" the exchange rate. ${ }^{9}$ Lastly, on the few occasions they have been adopted, free floats have proven much less durable in developing countries. Since 1975, eight developing countries have transitioned out of a freely floating regime; of these, six moved to freely falling episodes. This suggests that a truly free float arrangement may carry disadvantages for countries with a relatively less developed financial and institutional infrastructure.

If historical regime transition rates persist, and absent major political shifts toward currency unions, the number of pegged regimes in emerging markets and developing

\footnotetext{
${ }^{9}$ The only emerging market countries to move to a freely floating exchange rate since 1975 have been Malaysia (1998), Indonesia (1999), Korea (1999), and South Africa (1995). Of these, Malaysia transitioned to a peg during the following year, while the others maintained a float through 2001.
} 
countries is likely to decline further. As Figure 3 illustrates, over one half of all developing countries and emerging markets had rigid regimes in 1975. By 2001, this ratio had declined to under 40 percent. With the same rates of regime transition, pegs would constitute only about one third of all regimes by 2020. As developing countries become increasingly integrated into global financial markets, however, the durability of alternative exchange rate regimes in those countries may well resemble average regime durability rates seen among emerging markets during the 1980s and 1990s. In that case, the proportion of pegged regimes among developing countries will decline even more, and the proportion of pegs in all developing country and emerging market regimes will ease to less than one fourth. ${ }^{10}$

\section{Regime Performance}

An important prediction from economic theory is that exchange rate pegs act as a disciplining device, allowing policy makers in countries with a high inflation propensity to import credibility and, hence, lower inflation from abroad (Giavazzi and Giovannini, 1989; and Dornbusch, 2001). As a policy prescription, nominal exchange rate rigidity—or an exchange rate anchor — came back into favor in the late 1980s and early 1990s, especially in Latin America, where exchange-rate based stabilizations were viewed as particularly helpful

${ }^{10}$ It turns out that assuming that emerging market transition rates over the next two decades will be similar to advanced country transition rates over the past two decades does not meaningfully change the estimated distribution of developing country and emerging market regimes in 2020 depicted in Figure 3. Over the longer term, of course, political economy considerations may guide regime choice in some countries. For example, some countries may choose to join currency unions in the not so distant future. Prospects for regime transitions of that nature cannot be assessed on the basis of historical regime durability, however, and are clearly beyond the scope of this analysis. 
following a history of high inflation (Edwards, 2001). In this line of reasoning, the harder the peg, the more effective it is in enhancing credibility (Edwards and Magendzo, 2003a).

The proposition that pegs provide an inflation advantage is far from universally held, however. As exposure to international capital flows increases, a larger fraction of the monetary aggregates needs to be backed to maintain the peg. Hence, emerging markets are less likely to be able to import credibility than other developing countries where interaction with international capital markets is more limited. Tornell and Velasco (2000) raise the possibility that the inflationary gains from fixed regimes are illusory. No exchange rate system, they argue, can ultimately act as a substitute for sound macroeconomic policies. Far from exerting discipline, fixed exchange rate regimes may create an incentive for governments with short time horizons to cheat, delivering temporarily higher growth through larger deficits, with the full inflationary cost of such policies borne following the eventual collapse of the peg.

The theoretical implications of exchange rate regimes for economic growth and volatility are similarly murky, with various opposing claims. ${ }^{11}$ In favor of pegs, Dornbusch (2001) argues that lower inflation associated with rigid exchange rate regimes would reduce interest rates and uncertainty, spurring investment and growth. ${ }^{12}$ Also, where a country ties its currency tightly to that of another through a currency board arrangement, transactions

\footnotetext{
${ }^{11}$ For a useful summary, see Bailliu, Lafrance, and Perrault, 2002.

12 Such a beneficial outcome may have prevailed in the post-convertibility Bretton-Woods period from 1959-1971 when inflation and exchange rate volatility were low and growth was relatively strong (Bordo, 2003). However, it is not clear whether this was the consequence of the rigidity in exchange rate regimes or a generally favorable economic environment.
} 
costs may be lowered, increasing trade between the two countries. Frankel and Rose (2002) find that such expansion of trade is not offset by diversion away from other trade partners and, hence, by increasing the openness of the economy, this form of exchange rate rigidity also raises output growth. An argument in favor of exchange rate flexibility is the possibility of rapid resource reallocation following real shocks where short-run price rigidity is significant (Levy-Yeyati and Sturzenegger, 2003). Broda (2001) finds evidence that terms of trade shocks are amplified in countries that have more rigid exchange rate regimes. Edwards and Levy-Yeyati (2003) take that empirical analysis one step further and conclude that the inability of rigid regimes to absorb such shocks translates, in practice, into lower growth. Similarly, Calvo (1999) argues that the need to defend a peg following a negative external shock may result in high real interest rates and also stifle growth.

While flexible exchange rate regimes may, in principle, dampen real shocks to the economy, could the very flexibility of the exchange rate introduce a new element of volatility? As noted above, a robust finding is that nominal exchange rate volatility is associated with high real exchange rate volatility. Rogoff (1999) argues that such variability does not, in practice, have significant effects on output and consumption in advanced economies but may be harmful in developing countries. However, even if the higher volatility has harmful effects, pegged regimes may not be the appropriate policy response since the volatility may only apparently be contained and have real (adverse) effects on private investment due to the greater uncertainty over regime sustainability.

Indeed, just as the inflation-reducing benefits of exchange rate rigidity were being emphasized in the early 1990s, a fundamental reevaluation of the policy prescription was underway following the early crises associated with rigid regimes (for early recognition of 
this concern, see, for example, Eichengreen, 1994; and Obstfeld and Rogoff, 1995). Obstfeld and Rogoff noted in 1995, following the collapse of the British pound in September 1992 and of the Mexican peso in December 1994, that: "Many recent efforts to peg exchange rates within narrow ranges have ended in spectacular debacles." They went on to conclude: "These events are not unprecedented but their ferocity and scope have called into question the viability of fixed rates among sovereign nations in today's world of highly developed global capital markets." The subsequent fall of tightly managed regimes in East Asia (1997), Russia (1998), Brazil (1999), and Argentina (2002), has served as a continuing warning against pegged regimes, especially in emerging markets subject to volatile capital flows. Pegged exchange rates — or those with limited flexibility — invite speculative activity against the exchange rate and lead to abandonment of the peg, currency overshooting, and large output costs (Larrain and Velasco, 2001). Pegged regimes may also be subject to a higher incidence of banking crises. Under pegs, the exchange rate may become progressively overvalued, weakening the financial system; without (or with only limited) lender of last resort capabilities, authorities may be unable to deal with domestic financial distress.

\subsection{Inflation, growth, and volatility under alternative regimes}

Conflicting policy objectives and large macroeconomic imbalances will lead to poor economic performance irrespective of the exchange rate regime. For the purposes of this discussion, there are at least two sets of conditions under which the exchange rate regime may have no independent influence on macroeconomic outcomes through the prevailing severity of economic distortions. First, the prevalence of dual (or multiple) rates — and, hence, potentially a large differential in official and "parallel" market exchange rates - is, as 
in Reinhart and Rogoff (2004), a consideration in determining the operative regime as well as a factor influencing economic outcomes. Second, Reinhart and Rogoff (2004) isolate countries with annual inflation rates above 40 percent into a separate "freely falling" category, with the implication that the macroeconomic imbalances in such conditions overwhelm the possible effects of the exchange rate regime.

The evidence suggests that dual exchange rates are associated with significantly worse economic performance. Over the period 1970-99, the average per capita income growth rate in countries with dual exchange rates was about 0.6 percent per year; in contrast, countries with unified rates grew at three times the pace, at about 1.8 percent per year (Table 2). Similarly, annual inflation in countries with dual exchange rates was about 175 percent, while under unified rates it was about 22 percent. These performance differences primarily reflect instances of large departures from official rates- the differences in median performance are less egregious. With increasingly integrated capital markets, large gaps in official and parallel rates have become untenable and the move to unified exchange rates has been almost universal.

By construction, "freely falling" regimes perform significantly worse than other regimes on all counts: they have higher inflation and also lower growth rates and higher volatility (Tables 3, 4, and 5). With the worldwide decline in inflation, the incidence of freely falling regimes is on the decline (Rogoff, 2003). However, for retrospective analyses, since freely falling episodes are typically classified under other systems as freely floating, their identification as a separate category in the Natural classification can make a significant difference to the relative rankings of regimes. For example, according to the de jure classification (the last column in Table 3), pegs have much lower inflation than floating 
regimes. Under the Natural classification (the bottom row of Table 3), however, freely floating regimes have, on average, lower inflation than exchange rate pegs. This reversal occurs because, as noted, many freely falling episodes are in the floating regime category according to the de jure classification. When other influences on inflation are controlled for (see below), the advantage of pegged and intermediate regimes over the floating regime reappears even in the Natural classification; however, not distinguishing the freely falling category renders that advantage much larger.

The performance of intermediate regimes is not especially different from that of other regimes. This is consistent with the longevity of these regimes, as documented above. If this comparison had revealed consistently poorer performance under intermediate regimes, there would have been greater basis for expecting a shift to the polar extremes of pegs and floats.

Finally, as documented by Mussa (1986), Baxter and Stockman (1989), and Flood and Rose (1995), real exchange rates are more variable, the greater the flexibility of the regime (Table 6). Exchange rate volatility is considerably higher under managed floating and freely floating regimes than under pegged and limited flexibility regimes. This reflects the fact that real rates tend, at least in the short-run, to move closely with nominal rates. Notably, more flexibility under the de jure classification is not associated with greater variability of the real exchange rate since regimes that are declared flexible are often tightly managed.

\subsection{Regimes and crisis probabilities}

In the 1990s, several economies with rigid exchange rate regimes were victims of severe economic crises. A concern thus arose, not just for the prospects of the economies directly subject to the crises, but also for the possible "contagion" of crises across countries 
with similar economic features following a general loss of investor confidence. The occurrence of crises has, therefore, acquired greater prominence in the policy discussions on the choice of exchange rate regimes. Despite the policy interest, few systematic studies have examined the links between crises and exchange rate regimes.

The evidence presented below suggests that popular perception in this regard has some statistical basis. While the evidence on currency crises is mixed, the frequency of banking and "twin" crises (where banking and currency turbulence comes together) has been higher under more rigid regimes but mainly for emerging markets and particularly so in the 1990s. Emerging markets are more exposed to international capital flows than are other developing economies; but compared to advanced industrialized economies, emerging markets have fragile financial sectors. ${ }^{13}$

The banking crisis variable is taken from Demirguc-Kunt and Detragiache (1998). They define a banking crisis to have occurred when any one of the following four conditions held: (a) non-performing loans exceeded 10 percent of banking system assets; (b) a bailout cost 2 percent or more of GDP; (c) large scale nationalization occurred; or (d) other emergency measures, such bank holidays, deposit freezes, and special guarantees had to be undertaken. The currency or balance-of-payments crisis variable is taken from Berg, Borensztein, and Pattillo (2004), who define a crisis as having occurred when the weighted average of one-month changes in exchange rate and reserves is more than three (countryspecific) standard deviations above the country average.

${ }^{13}$ Any definition of emerging markets is likely to include and exclude countries on the margin in ways that are more or less appropriate. Extensive robustness tests were undertaken and only the most robust results are highlighted in the text. 
Consider, first, the frequency of banking crises. ${ }^{14}$ More rigid regimes had a higher likelihood of banking crises, especially in the 1990s. For all countries, for the period from 1980-1997, the probability of a banking crisis in a given year varied between about 3 and 4.5 percent with no clear variation across exchange rate regimes (Table 7). However, the highest probabilities of a banking crisis occurred in the emerging market economies, where the evidence also suggests that the probability of a crisis increased with the rigidity of the exchange rate regime. Moreover, the association between rigidity and probability of banking crises in emerging markets became stronger in the 1990s.

The finding that banking crises are more likely under rigid regimes is in contrast to that of Ghosh, Gulde, and Wolf (2003), who conclude that, if anything, floating regimes are the most likely to experience banking crises. The difference in findings is the consequence of their use of the de jure classification, which has many more countries classified as "floating" than does the Natural classification. As shown in Figure 1, many of these de jure "floaters" are classified under the Natural Classification as "freely falling;" other "floaters" did not actually float and so were de facto under more rigid regime categories. As a consequence, using the de jure classification leads to an overstatement of the likelihood of banking crises under floating regimes and an understatement of crisis probabilities under more rigid regimes.

\footnotetext{
${ }^{14}$ Crisis probabilities were obtained as the ratio of crises episodes under a particular regime divided by the number of regime-years. Each crisis was treated as a single episode even if it lasted for multiple years. The estimates presented drop the year of the crisis itself as well as the years immediately preceding and following the regime change to minimize the influence of the regime transition on occurrence of crises.
} 
Currency crises over the years 1970 to 2000 tended to occur more frequently in intermediate regimes. The evidence for the 1990s is less clear-cut and suggests that among emerging markets pegged regimes had more frequent currency crises. An alternative measure of currency crises, using different thresholds for exchange rate depreciation and loss in reserves (Bordo, Eichengreen, Klingebiel, and Soledad-Martinez, 2001) shows that, for emerging markets, pegs and limited flexibility had significantly higher risk of currency crisis than managed or freely floating regimes. ${ }^{15}$

Finally, "twin crises," when banking and currency crises coincide, have been almost uniquely an emerging market phenomenon: they have never occurred in the group of countries classified as "developing" and rarely in advanced economies. Moreover, the incidence of twin crises in emerging markets is highest under pegged regimes and falls as regime flexibility increases. Kaminsky and Reinhart (1999) have noted that twin crises have particularly high costs. Such crises typically start with domestic financial distress, which accelerates when a currency crisis also sets in, leading to a "vicious cycle." Costs are high in terms of the bailout costs of the financial sector as well as in terms of reserves lost. Larrain and Velasco (2001) provide a theoretical discussion of why currency boards may be particularly prone to twin crises. Rigid regimes may promote excessive risk-taking during periods of "booms" in capital inflows, when the expectation of an exchange rate guarantee reduces the incentive to hedge foreign currency exposure. The sudden withdrawal of flows leaves the domestic financial sector susceptible to severe distress. At the same time, the

\footnotetext{
${ }^{15}$ Bubula and Ötker-Robe (2003) continue to find vulnerability in the intermediate regimes in the 1990s but they do not distinguish emerging markets.
} 
commitment to an exchange rate target limits lender of last resort operations. If depositors withdraw domestic currency from domestic banks to buy the foreign reserve currency at the central bank, under a fixed exchange rate, the panic withdrawal can lead to a self-fulfilling crisis as foreign currency reserves are depleted. Argentina's massive collapse is a cautionary tale of how some of these forces can contribute to the unraveling of even a hard peg.

\subsection{Econometric analysis}

While the previous section reported correlations, this section takes the more demanding step of attempting to isolate, over the period 1970 to 1999, the association between exchange rate regimes and the performance measures of interest, after controlling for other variables that may also influence performance. ${ }^{16}$ But even after such controls are included, reverse causality, or "endogeneity," remains a concern in such analyses: in other words, the observed relationships may reflect the influence of the performance variable on the choice of the regime rather than the other way around. This problem cannot be fully resolved but is mitigated by the relatively long duration of the typical regime under the Natural classification, implying that temporary changes in performance do not influence the

${ }^{16}$ In addition to variables that are conventionally used to explain the different dimensions of performance (discussed below), two further sets of controls are used throughout. First, common shocks across countries (such as spikes in oil prices or changes in the volatility of G-3 currencies), influence all economies beyond the effect channeled through observed variables. These are controlled for through the use of time dummies. Second, while an increasing number of country control variables can be added, certain unobserved or difficult to measure country characteristics may reflect important dimensions of institutions and policy credibility. These, in turn, are likely to be correlated with exchange rate regimes; to control for these unobserved characteristics, country dummies are included. The implication of this approach is that regime performance is judged by changes that occur within a country rather than across countries. 
choice of regime. The problem is also mitigated by using as an explanatory variable the regime prevailing in the previous one or two years and the results presented are unchanged when that is done. ${ }^{17}$

Much of the data are taken from Ghosh, Gulde, and Wolf (2003), including the de jure classification of exchange rate regimes, the three measures of economic performance (inflation, growth, growth volatility), and the control (or explanatory) variables used in the regression analysis. Each variable is covered at an annual frequency from 1970 to 1999 for up to 158 countries. The control variables are drawn from the literature and are thought to provide a suitable explanation of the variations in the performance measures. Table 8 provides a detailed description of the data. It lists each variable, provides a brief description, and notes which of the subsequent regressions feature these variables. Using these data has the advantage that the evaluation of performance under the Natural classification can be directly compared to a well-respected baseline that assesses performance across the de jure regimes.

Our focus in this discussion is on the coefficients on "dummy," or categorical, variables representing the exchange rate regime. The dummy variable takes the value 1 if the exchange rate regime prevails in a country in a particular year; otherwise, it is assigned a value of zero. The coefficients presented in figures are to be interpreted as measures of performance (relative to the excluded pegged regime) and conditional upon the other included variables in the regression.

${ }^{17}$ Moreover, it is difficult to identify country characteristics that consistently predict exchange rate regimes. Since regimes are strongly persistent, they are likely to be the best predictors of expected regimes. 
Table 9 evaluates inflation performance across all countries, advanced countries, emerging markets, and developing countries. Three different specifications are presented: (1) the estimates with country fixed effects; (2) the same specification but without fixed effects; and (3) a specification with fixed effects but with the regime variables lagged by two years. The lagging of the exchange rate regime variables increases the likelihood, though does not ensure, that the results reflect the influence of regimes on performance rather than the other way around. Table 10 is analogous, except that it examines growth performance. The different specifications show that the qualitative direction of the key results presented hold up with considerable consistency.

To summarize, these results suggest that the performance of alternative exchange rate regimes, and hence the choice of the appropriate regime, depends importantly on the maturity of member countries' economies and their institutions. Developing economies that have limited interactions with international capital markets appear to benefit from policies that imply strong commitment to stable exchange rate and monetary policies. The harder end of the commitment in exchange rate regimes - either fixed or close to fixed exchange ratesdelivers lower inflation without sacrificing economic growth. Alternatively, more flexible regimes are associated with higher inflation but no evident gain in growth. The inflation result is highly robust to various changes in specification and almost always shows the pattern of increasing inflation with the degree of flexibility, as shown in Table 9. ${ }^{18}$ This

\footnotetext{
${ }^{18}$ For example, dropping "small" countries with populations less than 1 million and using an even finer differentiation of exchange rate regimes does not change the basic thrust and significance of these results.
} 
evidence complements the finding that relatively poor and small countries benefit in the form of enhanced trade from currency unions (Rose, 2004, and Thom and Walsh, 2002).

For emerging markets - those developing countries that have significant exposure to international capital markets - inflation tends also to be lower in regimes with harder commitment to exchange rate stability relative to floating regimes, though the difference is smaller than for developing economies (and not always statistically significant). Hence, there may be some value to commitment. However, as noted in Table 7, the evidence also suggests that where commitments are very hard, i.e., with pegged or nearly pegged regimes, the likelihood of financial crises is high, reflecting the inability to adapt to changed circumstances, the incentives of entrepreneurs and financial agents to undertake risky activities on the presumption that exchange rates will not change, and speculative pressures from investors who seek to test the commitment (Rogoff et al. 2004). ${ }^{19}$ Thus, commitment may deliver macroeconomic stability in the form of slightly lower inflation, on average, but those gains may unravel in periodic crises.

Finally, our results seem to suggest that more flexible regimes may be associated with somewhat lower inflation and higher growth in advanced economies. The regression with the

${ }^{19}$ Recall that emerging markets were distinguished from other developing countries by their exposure to international capital. Since there are no well-defined or generally accepted thresholds of exposure to international capital, the cut-off between high and low exposure can be arbitrary and was dealt with by dropping and adding countries on the margin to check the robustness of the results. For example, in checking for the robustness of results presented, India and China (considered to have relatively closed capital accounts) were dropped from the emerging markets sample but the results were unchanged. Countries added to the list included those that are not on the MSCI index but do appear on other international emerging market indices and also such countries as Bahrain, Lebanon, and Tunisia that are not on any list but are thought of as relatively open to international capital markets. Again, the results were robust. 
two-year lagged regime dummies, for example, shows a smooth increase in growth rates as the degree of flexibility increases. It is unclear what theoretical model delivers such a statistical result. Moreover, for both inflation and growth, the estimated differences across regimes are often not statistically significant and tend not to be robust across specifications. ${ }^{20}$ Nevertheless, the results do point to potential benefits to floating for advanced economies, and merit further study.

How do our results compare with those from other studies? Using data for the postBretton Woods era for over 100 countries, the analysis by Ghosh et al. (1997) and Ghosh, Gulde, and Wolf (2003) also found that inflation under fixed exchange rate regimes was significantly lower than under intermediate or freely floating arrangements, due to greater confidence in the currency (a credibility effect) and lower money growth (a discipline effect), and that the benefit of pegged exchange rate regimes in terms of inflation performance was fairly robust to the endogeneity of regime choice. They did not, however, distinguish between groups of countries as we have to identify that this effect applies mainly to relatively low-income developing countries. Levy-Yeyati and Sturzenegger (2002) used their own de facto classification of regimes and found, for a similar sample, that flexible exchange rates

\footnotetext{
${ }^{20}$ The results change with inclusion or exclusion of specific countries but generally show a positive coefficient on the floating regime. The results presented drop Kuwait, which experienced very rapid growth following the end of the Gulf War in 1992 and also had a floating regime at that time. Inclusion of Kuwait leads to a higher and less plausible advantage for floating rate regimes. Restricting the sample to OECD economies gives the same qualitative result, with the floating advantage being smaller but statistically significant. The results also remain when we drop countries belonging to the European Monetary Union.
} 
are associated with higher growth in developing countries (including emerging markets); no similar association existed among industrial countries. ${ }^{21}$

\section{CONCLUSIONS}

Our analysis suggests that the popular notion that pegged exchange rates are problematic everywhere is misplaced. We find, on the one hand, that fixed regimes in poorer developing countries with little access to international capital are associated with lower inflation and higher durability. For emerging markets, on the other hand, our results are more in line with the earlier Baxter-Stockman finding of the absence of any robust relation between economic performance and exchange rate regime. However, emerging markets do appear to experience crises more frequently under pegged regimes. And for advanced economies, we present evidence suggesting that flexible rates may offer significantly greater durability and slightly higher growth, without generating higher inflation. Naturally, exchange rate regimes are a sufficiently broad sweeping and complex topic that much further research is needed to cement these findings and to understand their microeconomic underpinnings. But, going forward, we would argue that further studies need to rely on more sophisticated de facto classifications of exchange rate regimes, such as the "Natural classification" we have used. In particular, exchange rate regime performance should be based on classifications that not only look at actual exchange rate behavior but also focus on market-based, rather than official, exchange rates.

\footnotetext{
${ }^{21}$ Several missing and inconclusive observations in the Levy-Yeyati and Sturzenegger (2003) classification raise concerns about their conclusions.
} 


\section{REFERENCES}

Bailliu, J., Lafrance, R., Perrault, J-F., 2002. Does Exchange Rate Policy Matter for Growth? Bank of Canada Working Paper 2002-17.

Baxter, M., Stockman, A., 1989. Business Cycles and the Exchange-Rate Regime: Some International Evidence. Journal of Monetary Economics, Vol. 23 (May), pp. 377-400.

Berg, A. G., Borensztein, E.R., Pattillo, C.A., 2004. Assessing Early Warning Systems: How Have They Worked in Practice? IMF Working Paper No. 04/52 (Washington: International Monetary Fund).

Bordo, M. D., 2003. Exchange Rate Regime Choice in Historical Perspective. NBER Working Paper 9654 (Cambridge, Massachusetts: National Bureau of Economic Research).

Bordo, M. D., Eichengreen, B., Klingebiel, D., Soledad-Martinez, M., 2001. Financial Crises: Lessons from the Last 120 Years. Economic Policy: A European Forum, No. 32 , pp. 51-82.

Broda, C., 2001. Coping with Terms-of-Trade Shocks: Pegs versus Floats. American Economic Review, Papers and Proceedings, Vol. 91, No. 2 (May), pp. 376-80.

Bubula, A., Ötker-Robe, I., 2002. The Evolution of Exchange Rate Regimes since 1990: Evidence from De Facto Policies. IMF Working Paper 02/155 (Washington: International Monetary Fund).

Bubula, A., Ötker-Robe, I., 2003. Are Pegged and Intermediate Exchange Rate Regimes More Crisis Prone? IMF Working Paper 03/223 (Washington: International Monetary Fund). 
Calvo, G. A., 1999. Fixed Versus Flexible Exchange Rates: Preliminaries of a Turn-ofMillennium Rematch. Unpublished manuscript.

Demirigüç-Kunt, A., Detragiache, E., 1998. The Determinants of Banking Crises in Developing and Developed Countries. IMF Staff Papers Vol. 25, No. 1 (Washington: International Monetary Fund).

Dooley, M., Folkerts-Landau, D., Garber, P., 2004. The Revived Bretton Woods System: The Effects of Periphery Intervention and Reserve Management on Interest Rates and Exchange Rates in Center Countries. NBER Working Paper No. 10332 (Cambridge, Massachusetts: National Bureau of Economic Research).

Dornbusch, R., 2001. Fewer Monies, Better Monies. NBER Working Paper 8324 (Cambridge, Massachusetts: National Bureau of Economic Research).

Duttagupta, R., Ötker-Robe, I., 2003. Exits from Pegged Regimes: An Empirical Analysis. IMF Working Paper 03/147 (Washington: International Monetary Fund).

Edwards, S., 2001. Exchange Rate Regimes, Capital Flows and Crisis Prevention. NBER Working Paper 8529 (Cambridge, Massachusetts: National Bureau of Economic Research).

Edwards, S., Levy-Yeyati, E., 2003. Flexible Exchange Rates as Shock Absorbers. NBER Working Paper No. 9867 (Cambridge, Massachusetts: National Bureau of Economic Research).

Edwards, S., Magendzo, I., 2003a. A Currency of One's Own? An Empirical Investigation on Dollarization and Independent Currency Unions. NBER Working Paper 9514 (Cambridge, Massachusetts: National Bureau of Economic Research). 
Eichengreen, B., 1994. International Monetary Arrangements for the $21^{\text {st }}$ Century (Washington: Brookings Institution).

Eichengreen, B., Masson, P., Bredenkamp, H., Johnston, B., Hamann, J., Jadresic, E., Ötker, Inci., 1998. Exit Strategies: Policy Options for Countries Seeking Greater Exchange Rate Flexibility. IMF Occasional Paper 168 (Washington: International Monetary Fund).

Fischer, S., 2001. Exchange Rate Regimes: Is the Bipolar View Correct?, Distinguished Lecture on Economics in Government. Journal of Economic Perspectives, Vol. 15, No. 2 (Spring), pp. 3-24.

Flood, R. P., Rose, A. K., 1995. Fixing Exchange Rates: A Virtual Quest for Fundamentals, Journal of Monetary Economics, Vol. 36 (August), pp. 3-37.

Frankel, J. A., Rose, A., 2002. An Estimate of the Effect of Common Currencies on Trade and Income. Quarterly Journal of Economics, Vol. 117, No. 2 (May), pp. 437-66.

Ghosh, A., Gulde, A-M., Ostry, J., Wolf, H., 1997. Does the Nominal Exchange Rate Regime Matter? NBER Working Paper 5874 (Cambridge, Massachusetts: National Bureau of Economic Research).

Ghosh, A., Gulde, A-M., Wolf, H. C., 2003. Exchange Rate Regimes: Choices and Consequences (Cambridge, Massachusetts: MIT Press).

Giavazzi, F., Giovannini, A., 1989. Limiting Exchange Rate Flexibility: The European Monetary System (Cambridge, Massachusetts: MIT Press).

Kaminsky, G., Reinhart, C., 1999. The Twin Crises: The Causes of Banking and Balance of Payments Problems. American Economic Review, Vol. 89 (June), pp. 473-500. 
Klein, M. W., Marion, N. P., 1997. Explaining the Duration of Exchange-Rate Pegs. Journal of Development Economics, Vol. 54, No. 2 (December), pp. 387-404.

Larraín, F., and Velasco, A., 2001. Exchange-Rate Policy in Emerging Market Economies: The Case for Floating. Essays in International Economics, No. 224 (Princeton, New Jersey: Princeton University).

Levy-Yeyati, E., Sturzenegger, F., 2002. Classifying Exchange Rate Regimes: Deeds versus Words. Universidad Torcuato Di Tella. Available via the Internet at: www.utdt.edu/ fsturzen.

Levy-Yeyati, E., Sturzenegger, F., 2003. To Float or to Fix: Evidence on the Impact of Exchange Rate Regimes on Growth. American Economic Review, Vol. 93, No. 4 (September), pp. 1173-93.

Masson, P. R.., 2001. Exchange Rate Regime Transitions. Journal of Development Economics, Vol. 64, No. 2 (April), pp. 571-86.

Mussa, M., 1986. Nominal Exchange Rate Regimes and the Behavior of Real Exchange Rates: Evidence and Implications. Carnegie-Rochester Conference Series on Public Policy, Vol. 25 (Fall), pp.117-214.

Obstfeld, M., Rogoff, K., 1995. Mirage of Fixed Exchange Rates. Journal of Economic Perspectives, Vol. 9 (Fall), pp. 73-96.

Prasad, E., Rogoff, K., Wei, S-J. Kose, M. A., 2003. Effects of Financial Globalization on Developing Countries: Some Empirical Evidence, IMF Occasional Paper 220 (Washington: International Monetary Fund). 
Reinhart, C. M. Rogoff, K., 2004. The Modern History of Exchange Rate Arrangements: A Reinterpretation. Quarterly Journal of Economics (forthcoming), available via the Internet: http://www.puaf.umd.edu/faculty/papers/reinhart/papers.htm.

Rogoff, K., 1999. Perspectives on Exchange Rate Regimes. International Capital Flows, ed. by Martin Feldstein, pp. 441-53 (Chicago: University of Chicago Press).

Rogoff, K., Husain, A. M., Mody, A., Brooks, R. J., Oomes, N., 2003. Evolution and Performance of Exchange Rate Regimes. IMF Working Paper No. 03/243 (Washington: International Monetary Fund).

Rose, A., 2004. A Meta-Analysis of the Effect of Common Currencies on International Trade. NBER Working Paper No. 10373 (Cambridge, Massachusetts: National Bureau of Economic Research).

Summers, L. H., 2000. International Financial Crises: Causes, Prevention, and Cures. American Economic Review, Papers and Proceedings, Vol. 90 (May), pp. 1-16.

Thom, R., and Walsh, B., 2002. The Effects of a Currency Union on Trade: Lessons from the Irish Experience. European Economic Review, Vol. 46, No. 6, pp. 1111-23.

Tornell, A., Velasco, A., 2000. Fixed versus Flexible Exchange Rates: Which Provides More Fiscal Discipline?

Williamson, J., 2000. Exchange Rate Regimes for Emerging Markets: Reviving the Intermediate Option (Washington: Institute for International Economics). 
Fig. 1. Natural Classification Regimes by De Jure Category, 1973-99 (In percent of annual observations)

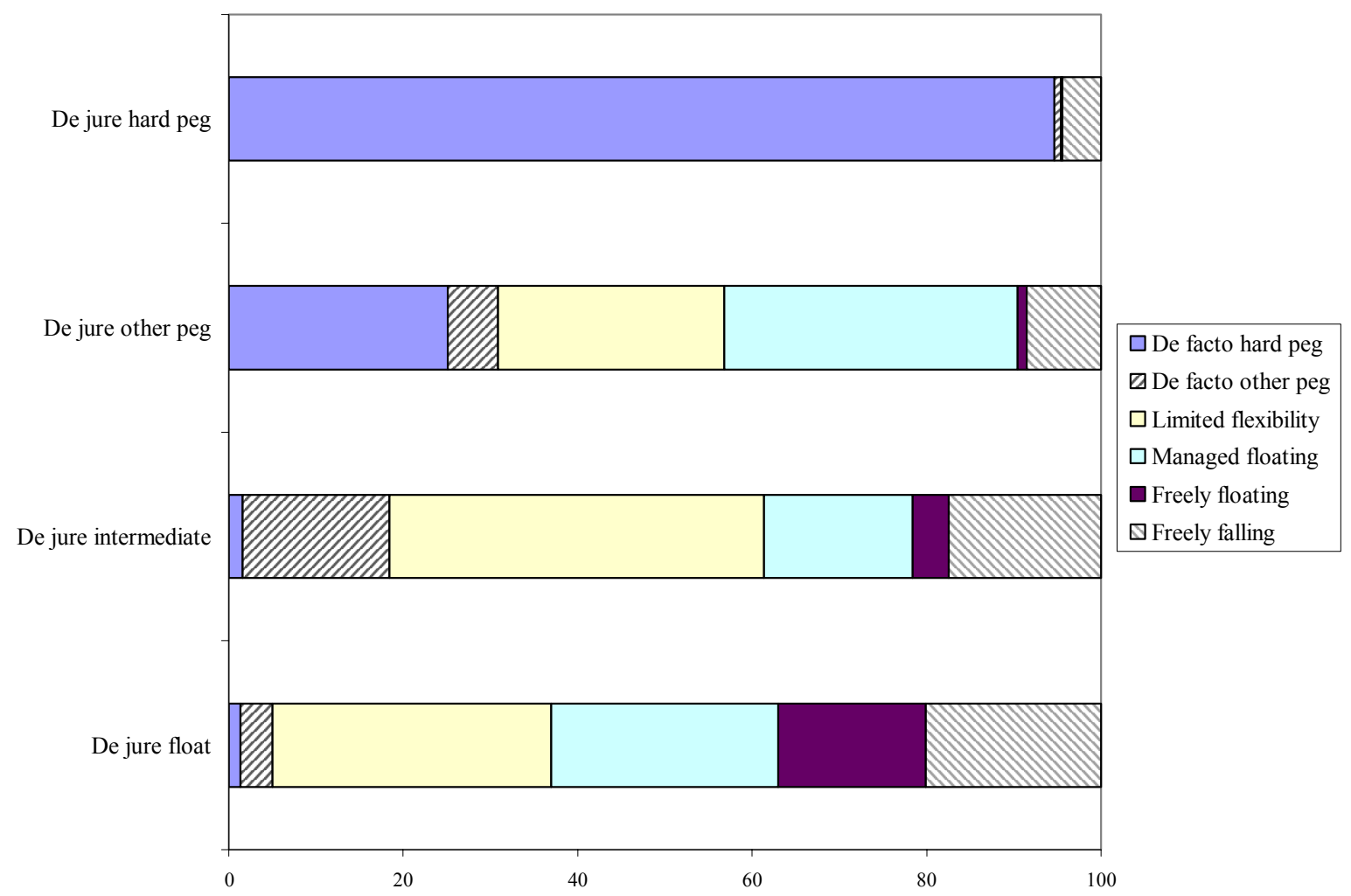

Sources: Reinhart and Rogoff (2004); Ghosh, Gulde, and Wolf (2003); and authors' estimates. 
Fig. 2. Natural Classification Regime Distribution (In percent of annual observations)

All Countries

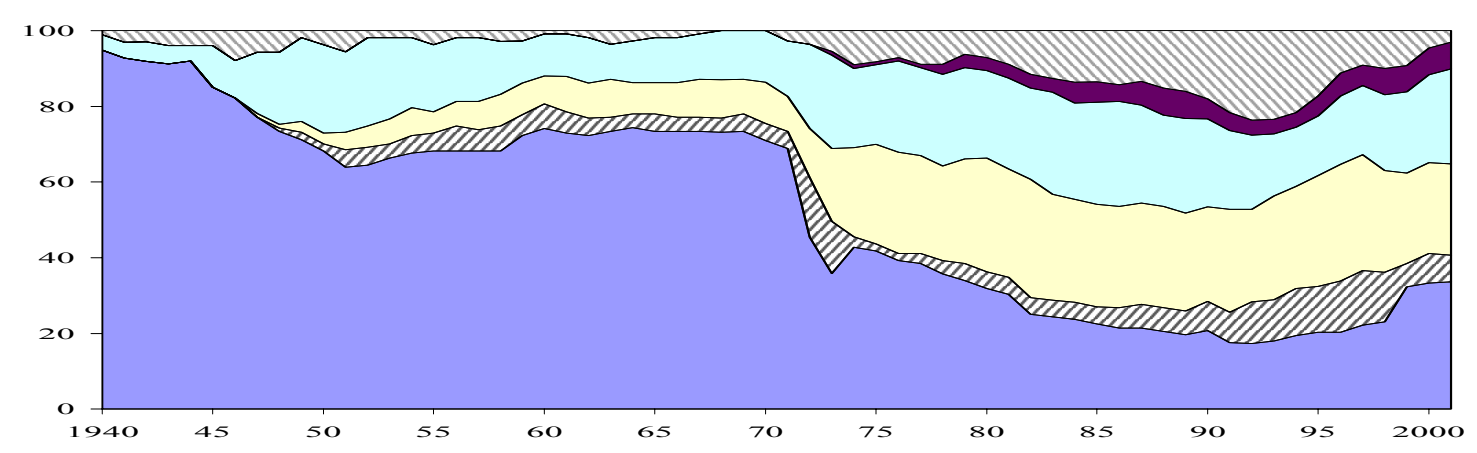

Advanced Countries

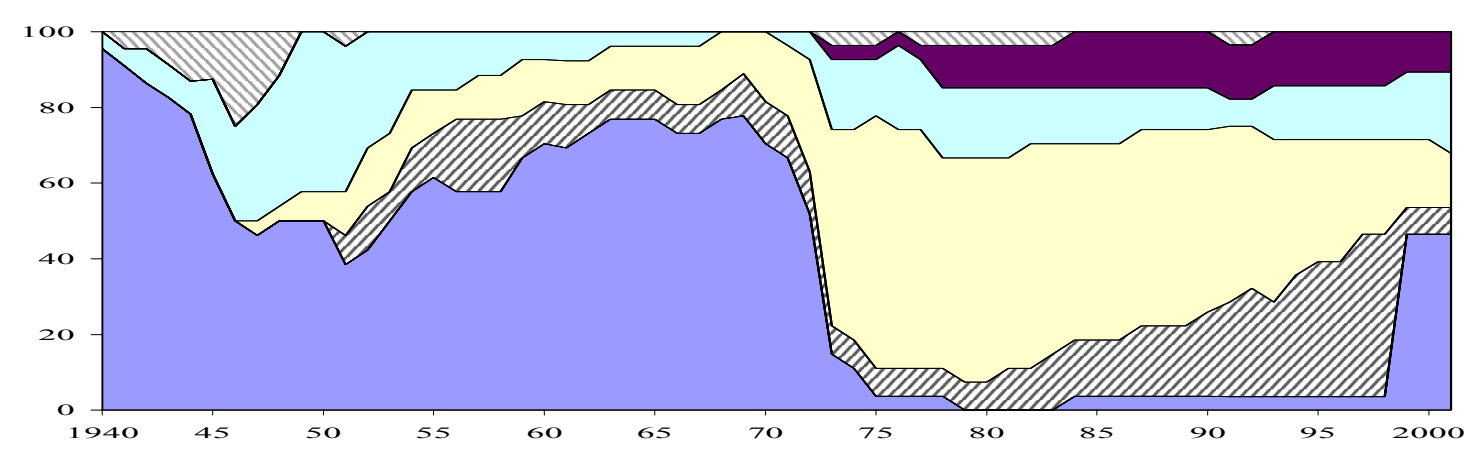

Emerging Markets
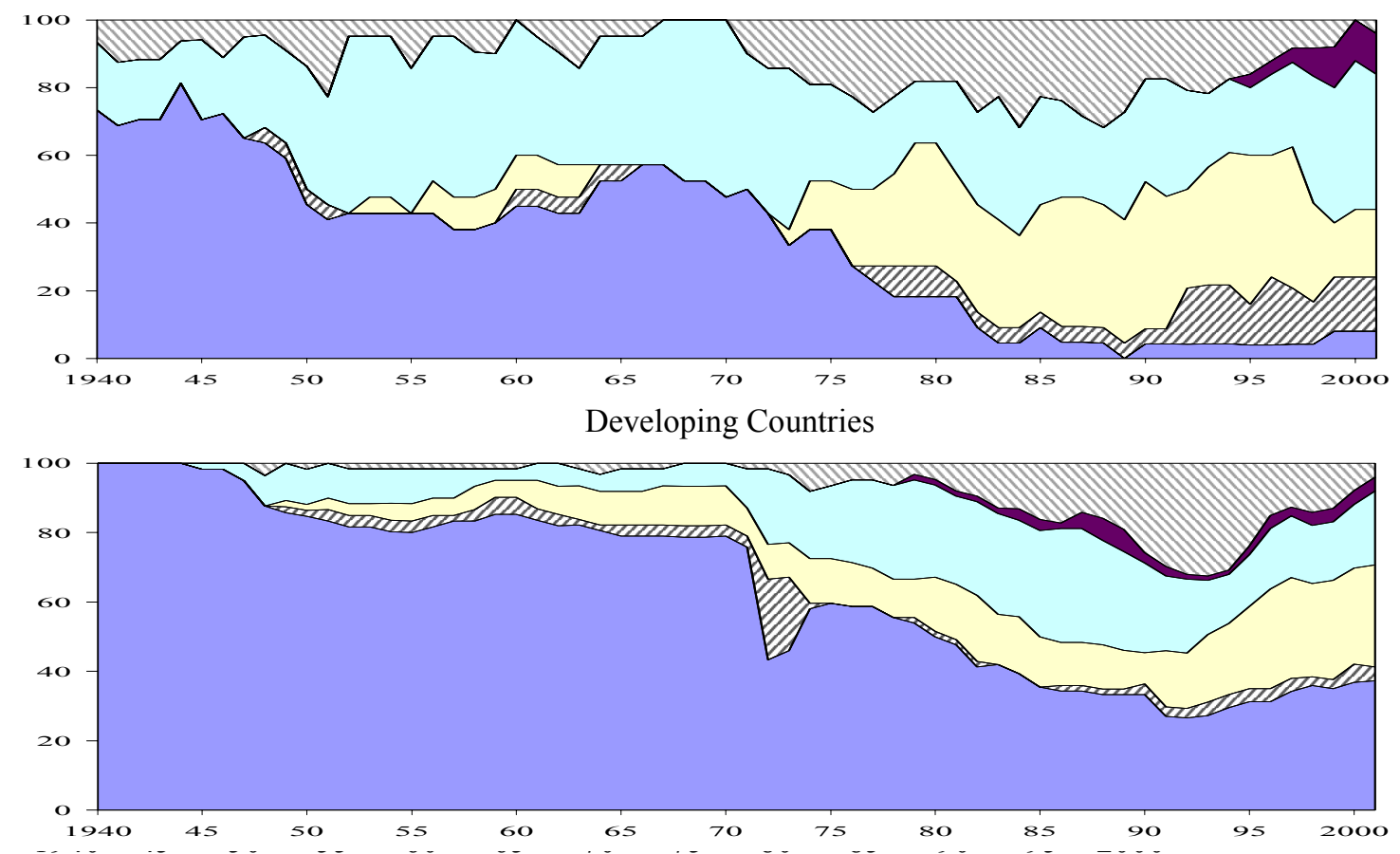

$\square$ Hard peg $\square$ Other peg $\square$ Limited flexibility $\square$ Managed floating $\square$ Freely floating $\square$ Freely falling

Sources: Reinhart and Rogoff (2004); and authors' estimates. 
Fig. 3. Natural Classification Regime Transitions (Number of transitions)

Advanced Countries

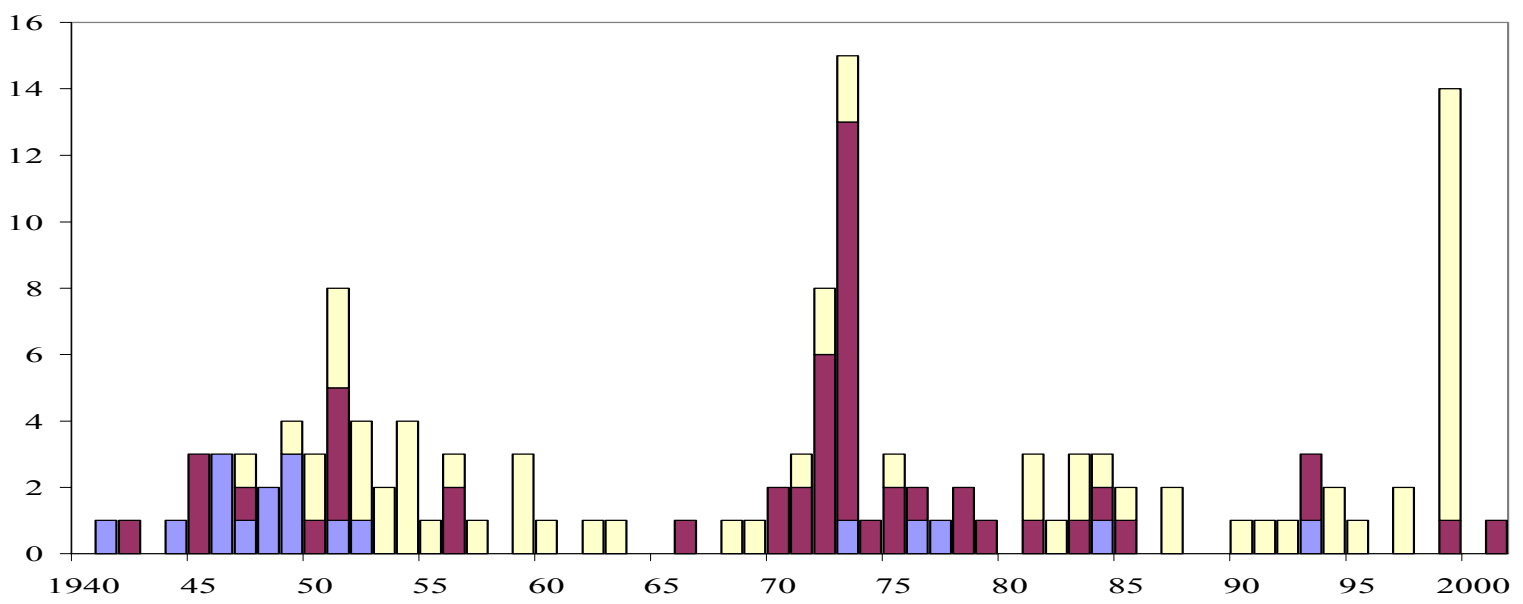

Emerging Markets
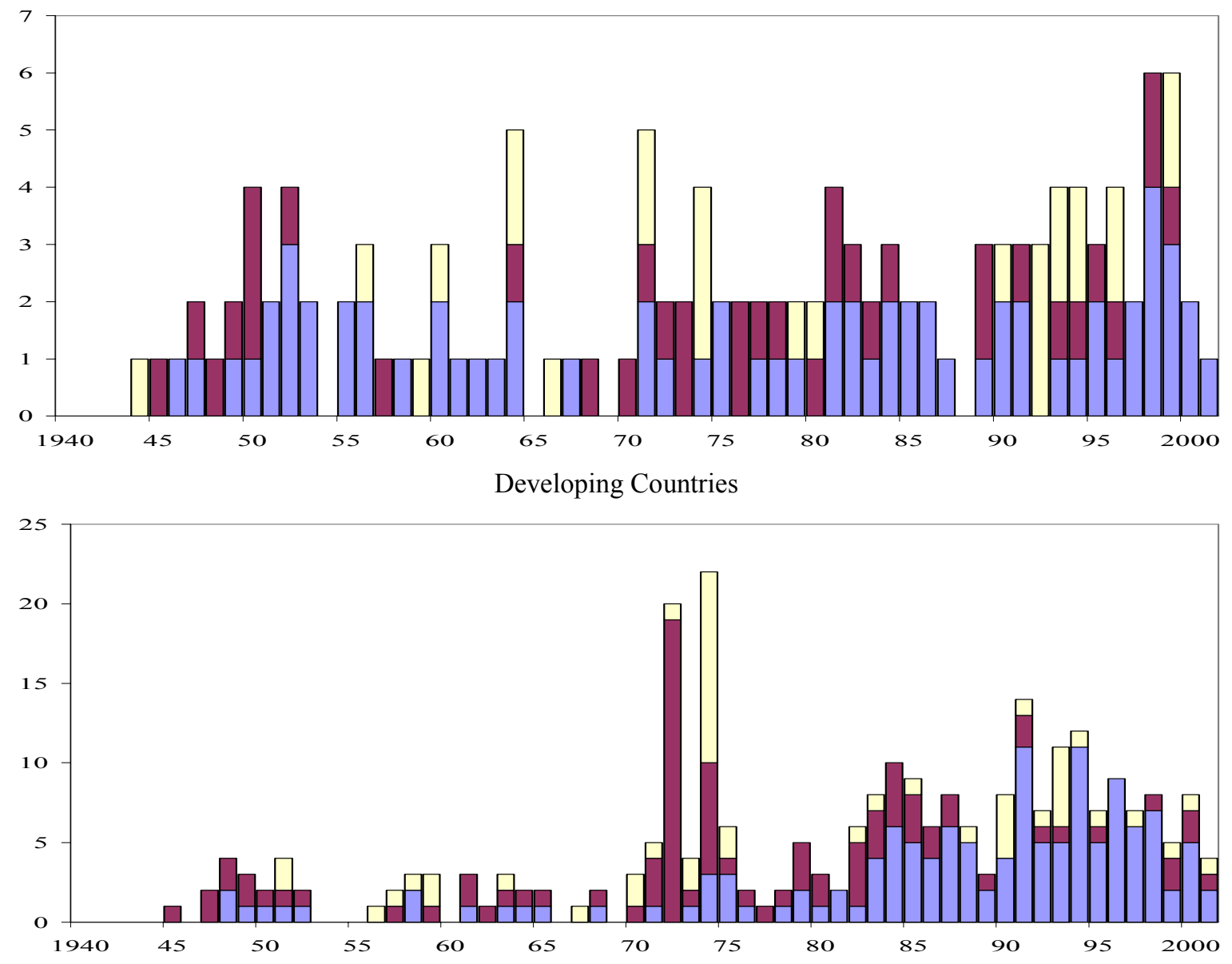

$\square$ To/from freely falling $\square$ To more flexible regime $\square$ To less flexible regime

Sources: Reinhart and Rogoff (2004); and authors' estimates. 
Fig. 4. Exchange Rate Regimes in Developing Countries and Emerging Markets (In percent of total regimes)
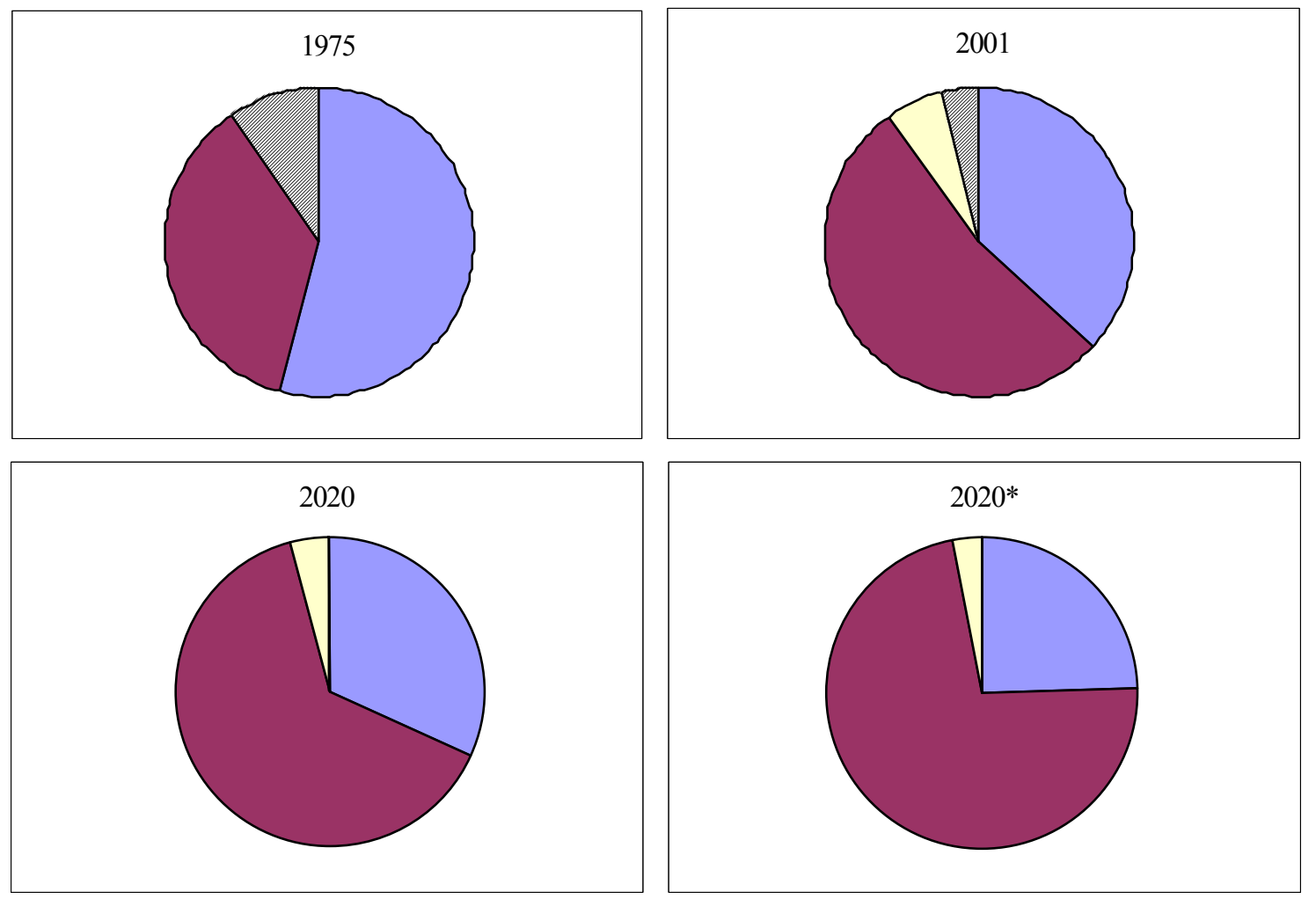

\section{$\square$ Pegs $\square$ Intermediates $\square$ Floats $\square$ Freely Falling}

* Assumes developing country regime transition rates equal to those for emerging markets.

Note: Future regime distributions calculated on the basis of transition probabilities during 1975-2001, and assuming no new transitions to freely falling category.

Source: Authors' estimates. 
Table 1. Regime Durability

(Average duration of regime, in years)

\begin{tabular}{|c|c|c|c|c|}
\hline & All regimes & Pegs & Intermediate & Floats \\
\hline \multicolumn{5}{|l|}{ 1940-2001 } \\
\hline All countries & 14.3 & 28.3 & 16.1 & 14.4 \\
\hline Advanced economies & 14.3 & 19.5 & 18.4 & 89.0 \\
\hline Emerging markets & 10.3 & 15.0 & 15.0 & 11.0 \\
\hline Developing countries & 16.3 & 40.9 & 15.5 & 5.5 \\
\hline \multicolumn{5}{|l|}{$1975-2001$} \\
\hline All countries & 11.4 & 23.2 & 18.4 & 14.3 \\
\hline Advanced economies & 19.4 & 46.0 & 26.8 & 88.0 \\
\hline Emerging markets & 8.6 & 8.4 & 16.5 & 11.0 \\
\hline Developing countries & 10.7 & 27.3 & 16.2 & 5.5 \\
\hline
\end{tabular}

Note: Regime durability is measured as the average number of years until a regime transition occurs, based on Natural classification data. Pegs include both "soft" and "hard" pegs, and transitions from one type of peg to another are not considered regime changes for these calculations. Similarly, transitions between different types of intermediate regimes (limited flexibility and managed floats) are not counted as regime changes. Estimated duration of all regimes includes duration of freely falling episodes.

Sources: Reinhart and Rogoff (2003) and authors' estimates. 
Table 2. Average Annual Inflation and Real Per Capita GDP Growth:

Comparison of Dual (or Multiple) and Unified Exchange Rate Systems, 1970-99 (In percent)

\begin{tabular}{lcc}
\hline \hline \multirow{2}{*}{ Regime } & $\begin{array}{c}\text { Average Annual Inflation } \\
\text { Rate }\end{array}$ & $\begin{array}{c}\text { Average Per Capita GDP } \\
\text { Growth }\end{array}$ \\
\hline Unified exchange rate & 22.0 & 1.8 \\
& $(7.7)$ & $(2.1)$ \\
Dual (or multiple) exchange rates & 175.6 & 0.6 \\
& $(15.1)$ & $(1.4)$ \\
\hline
\end{tabular}

Note: Figures in parentheses are medians.

Source: Authors' estimates. 
Table 3. Average Annual Inflation Rates Across Exchange Rate Regimes, 1970-99 (In percent)

\begin{tabular}{|c|c|c|c|c|c|c|c|c|}
\hline & & \multicolumn{6}{|c|}{ Natural Classification } & \multirow[b]{2}{*}{ Total } \\
\hline & & Peg & $\begin{array}{l}\text { Limited } \\
\text { Flexibility }\end{array}$ & $\begin{array}{c}\text { Managed } \\
\text { Floating }\end{array}$ & $\begin{array}{c}\text { Freely } \\
\text { Floating }\end{array}$ & $\begin{array}{l}\text { Freely } \\
\text { Falling }\end{array}$ & Unknown & \\
\hline \multirow{3}{*}{$\begin{array}{l}\text { IMF De Jure } \\
\text { Classification }\end{array}$} & Pegged & $\begin{array}{l}17.9 \\
(6.8)\end{array}$ & $\begin{array}{c}9.6 \\
(7.9)\end{array}$ & $\begin{array}{c}14.2 \\
(10.4)\end{array}$ & $\begin{array}{l}24.5 \\
(23.2)\end{array}$ & $\begin{array}{l}391.7 \\
(39.9)\end{array}$ & $\begin{array}{l}12.4 \\
(6.5)\end{array}$ & $\begin{array}{l}33.9 \\
(7.9)\end{array}$ \\
\hline & Intermediate & $\begin{array}{l}11.2 \\
(3.5)\end{array}$ & $\begin{array}{l}13.0 \\
(9.1)\end{array}$ & $\begin{array}{c}16.7 \\
(15.1)\end{array}$ & $\begin{array}{c}9.2 \\
(3.8)\end{array}$ & $\begin{array}{c}147.6 \\
(66.1)\end{array}$ & $\begin{array}{c}25.7 \\
(15.9)\end{array}$ & $\begin{array}{c}36.0 \\
(10.8)\end{array}$ \\
\hline & Floating & $\begin{array}{c}20.3 \\
(11.5)\end{array}$ & $\begin{array}{l}10.1 \\
(7.5)\end{array}$ & $\begin{array}{l}11.3 \\
(8.4)\end{array}$ & $\begin{array}{c}8.1 \\
(4.5)\end{array}$ & $\begin{array}{l}408.9 \\
(68.6)\end{array}$ & $\begin{array}{l}445.6 \\
(22.2)\end{array}$ & $\begin{array}{l}138.5 \\
(10.8)\end{array}$ \\
\hline \multicolumn{2}{|r|}{ Total } & $\begin{array}{l}17.1 \\
(6.5)\end{array}$ & $\begin{array}{l}11.1 \\
(8.3)\end{array}$ & $\begin{array}{c}14.2 \\
(10.8)\end{array}$ & $\begin{array}{c}9.9 \\
(4.8)\end{array}$ & $\begin{array}{l}305.3 \\
(57.0)\end{array}$ & $\begin{array}{l}55.5 \\
(7.6)\end{array}$ & $\begin{array}{l}49.7 \\
(8.7)\end{array}$ \\
\hline
\end{tabular}

Note: Figures in parentheses are medians.

Source: Authors' estimates. 
Table 4. Average Annual Real Per Capita GDP Growth Across Exchange Rate Regimes, 1970-99 (In percent)

\begin{tabular}{|c|c|c|c|c|c|c|c|c|}
\hline & & \multicolumn{6}{|c|}{ Natural Classification } & \multirow[b]{2}{*}{ Total } \\
\hline & & Peg & $\begin{array}{c}\text { Limited } \\
\text { Flexibility }\end{array}$ & $\begin{array}{c}\text { Managed } \\
\text { Floating }\end{array}$ & $\begin{array}{c}\text { Freely } \\
\text { Floating }\end{array}$ & $\begin{array}{l}\text { Freely } \\
\text { Falling }\end{array}$ & Unknown & \\
\hline \multirow{4}{*}{$\begin{array}{l}\text { IMF De Jure } \\
\text { Classification }\end{array}$} & Pegged & $\begin{array}{c}2.0 \\
(2.0)\end{array}$ & $\begin{array}{l}2.6 \\
(2.6)\end{array}$ & $\begin{array}{l}1.6 \\
(1.6)\end{array}$ & $\begin{array}{l}-3.2 \\
(0.5)\end{array}$ & $\begin{array}{c}-1.1 \\
(-0.7)\end{array}$ & $\begin{array}{c}1.0 \\
(0.6)\end{array}$ & $\begin{array}{c}1.6 \\
(1.6)\end{array}$ \\
\hline & Intermediate & 2.8 & 2.6 & 1.9 & 2.7 & 0.0 & 2.7 & 2.1 \\
\hline & & $(2.4)$ & $(2.9)$ & $(2.1)$ & $(2.2)$ & $(0.4)$ & $(2.7)$ & $(2.3)$ \\
\hline & Floating & $\begin{array}{c}3.6 \\
(2.9)\end{array}$ & $\begin{array}{c}1.7 \\
(1.8)\end{array}$ & $\begin{array}{l}1.6 \\
(2.2)\end{array}$ & $\begin{array}{c}2.2 \\
(2.3)\end{array}$ & $\begin{array}{c}-3.1 \\
(-1.2)\end{array}$ & $\begin{array}{c}-1.6 \\
(-0.3)\end{array}$ & $\begin{array}{c}0.6 \\
(1.7)\end{array}$ \\
\hline \multicolumn{2}{|r|}{ Total } & $\begin{array}{c}2.1 \\
(2.2)\end{array}$ & $\begin{array}{c}2.4 \\
(2.6)\end{array}$ & $\begin{array}{c}1.7 \\
(2.0)\end{array}$ & $\begin{array}{c}1.8 \\
(2.0)\end{array}$ & $\begin{array}{c}-1.3 \\
(-0.6)\end{array}$ & $\begin{array}{c}0.8 \\
(0.6)\end{array}$ & $\begin{array}{c}1.5 \\
(1.8)\end{array}$ \\
\hline
\end{tabular}

Note: Figures in parentheses are medians.

Source: Authors' estimates. 
Table 5. Average Annual Growth Volatility Across Exchange Rate Regimes, 1970-99 (In percent)

\begin{tabular}{|c|c|c|c|c|c|c|c|c|}
\hline & & \multicolumn{6}{|c|}{ Natural Classification } & \multirow[b]{2}{*}{ Total } \\
\hline & & Peg & $\begin{array}{c}\text { Limited } \\
\text { Flexibility }\end{array}$ & $\begin{array}{c}\text { Managed } \\
\text { Floating }\end{array}$ & $\begin{array}{c}\text { Freely } \\
\text { Floating }\end{array}$ & $\begin{array}{l}\text { Freely } \\
\text { Falling }\end{array}$ & Unknown & \\
\hline \multirow{3}{*}{$\begin{array}{l}\text { IMF De Jure } \\
\text { Classification }\end{array}$} & Pegged & $\begin{array}{l}4.0 \\
(2.7)\end{array}$ & $\begin{array}{l}3.8 \\
(2.3)\end{array}$ & $\begin{array}{l}3.6 \\
(2.6)\end{array}$ & $\begin{array}{c}5.7 \\
(3.3)\end{array}$ & $\begin{array}{c}4.3 \\
(3.4)\end{array}$ & $\begin{array}{c}4.3 \\
(2.9)\end{array}$ & $\begin{array}{c}4.0 \\
(2.7)\end{array}$ \\
\hline & Intermediate & $\begin{array}{c}1.6 \\
(1.2)\end{array}$ & $\begin{array}{c}2.0 \\
(1.6)\end{array}$ & $\begin{array}{c}2.6 \\
(1.8)\end{array}$ & $\begin{array}{c}3.3 \\
(1.7)\end{array}$ & $\begin{array}{c}3.8 \\
(3.4)\end{array}$ & $\begin{array}{c}6.1 \\
(2.5)\end{array}$ & $\begin{array}{c}2.6 \\
(1.8)\end{array}$ \\
\hline & Floating & $\begin{array}{c}3.1 \\
(1.8)\end{array}$ & $\begin{array}{c}2.4 \\
(1.5)\end{array}$ & $\begin{array}{c}4.1 \\
(1.9)\end{array}$ & $\begin{array}{c}1.9 \\
(1.1)\end{array}$ & $\begin{array}{c}6.4 \\
(4.6)\end{array}$ & $\begin{array}{c}4.9 \\
(2.9)\end{array}$ & $\begin{array}{c}3.8 \\
(1.9)\end{array}$ \\
\hline & Total & $\begin{array}{c}3.7 \\
(2.4)\end{array}$ & $\begin{array}{c}2.8 \\
(1.8)\end{array}$ & $\begin{array}{c}3.5 \\
(2.3)\end{array}$ & $\begin{array}{c}2.7 \\
(1.3)\end{array}$ & $\begin{array}{c}4.7 \\
(3.7)\end{array}$ & $\begin{array}{c}4.5 \\
(2.9)\end{array}$ & $\begin{array}{c}3.7 \\
(2.4)\end{array}$ \\
\hline
\end{tabular}

Note: Figures in parentheses are medians.

Source: Authors' estimates. 
Table 6. Real Exchange Rate Volatility Across Exchange Rate Regimes, 1970-2002

\begin{tabular}{|c|c|c|c|c|c|c|c|c|}
\hline & & \multicolumn{6}{|c|}{ Natural Classification } & \multirow[b]{2}{*}{ Total } \\
\hline & & Peg & $\begin{array}{c}\text { Limited } \\
\text { Flexibility }\end{array}$ & $\begin{array}{c}\text { Managed } \\
\text { Floating }\end{array}$ & $\begin{array}{c}\text { Freely } \\
\text { Floating }\end{array}$ & $\begin{array}{l}\text { Freely } \\
\text { Falling }\end{array}$ & Unknown & \\
\hline \multirow{3}{*}{$\begin{array}{l}\text { IMF De Jure } \\
\text { Classification }\end{array}$} & Pegged & 6.3 & 8.9 & 25.1 & 7.0 & 53.6 & 6.6 & 12.7 \\
\hline & Intermediate & 3.2 & 4.8 & 10.5 & 30.6 & 42.3 & 28.4 & 12.1 \\
\hline & Floating & 10.5 & 5.2 & 11.6 & 8.4 & 17.3 & 14.8 & 10.4 \\
\hline \multicolumn{2}{|r|}{ Total } & 5.6 & 6.1 & 17.9 & 13.7 & 37.0 & 9.2 & 12.0 \\
\hline
\end{tabular}

Note: Volatility is measured as the three-year centered standard deviation of the annual real effective exchange rate (IFS, line RECZF). Nicaragua is excluded from this table because its exchange rate has been extremely volatile, and its inclusion unduly influences the averages.

Source: Authors' estimates. 
Table 7. Probability of Crises During Specific Regimes Using the Natural Exchange Rate Regime Classification (In percent)

\begin{tabular}{|c|c|c|c|c|c|c|c|c|}
\hline & \multicolumn{4}{|c|}{ Bank Crisis (1980-97) } & \multicolumn{4}{|c|}{ Bank Crisis (1990-97) } \\
\hline & Peg & $\begin{array}{c}\text { Limited } \\
\text { Flexibility }\end{array}$ & $\begin{array}{c}\text { Managed } \\
\text { Floating } \\
\end{array}$ & $\begin{array}{c}\text { Freely } \\
\text { Floating } \\
\end{array}$ & Peg & $\begin{array}{c}\text { Limited } \\
\text { Flexibility } \\
\end{array}$ & $\begin{array}{c}\text { Managed } \\
\text { Floating } \\
\end{array}$ & $\begin{array}{c}\text { Freely } \\
\text { Floating } \\
\end{array}$ \\
\hline All & 3.4 & 4.7 & 4.5 & 3.9 & 3.1 & 7.1 & 3.0 & 3.8 \\
\hline Advanced & 0.0 & 2.7 & 2.3 & 4.1 & 0.0 & 6.5 & 0.0 & 4.2 \\
\hline Emerging & 11.4 & 7.5 & 7.0 & 0.0 & 15.4 & 8.0 & 3.8 & 0.0 \\
\hline \multirow[t]{3}{*}{ Developing } & 2.8 & 7.0 & 3.6 & - & 2.6 & 7.1 & 4.5 & - \\
\hline & \multicolumn{4}{|c|}{ Balance of Payments Crisis (1970-2000) } & \multicolumn{4}{|c|}{ Balance of Payments Crisis (1990-2000) } \\
\hline & Peg & $\begin{array}{c}\text { Limited } \\
\text { Flexibility }\end{array}$ & $\begin{array}{c}\text { Managed } \\
\text { Floating } \\
\end{array}$ & $\begin{array}{c}\text { Freely } \\
\text { Floating } \\
\end{array}$ & Peg & $\begin{array}{c}\text { Limited } \\
\text { Flexibility } \\
\end{array}$ & $\begin{array}{c}\text { Managed } \\
\text { Floating } \\
\end{array}$ & $\begin{array}{c}\text { Freely } \\
\text { Floating }\end{array}$ \\
\hline All & 4.1 & 4.1 & 9.2 & 4.6 & 4.7 & 5.2 & 9.2 & 4.3 \\
\hline Advanced & 3.3 & 3.9 & 7.1 & 4.9 & 3.6 & 5.8 & 8.6 & 4.9 \\
\hline Emerging & 4.6 & 5.6 & 10.0 & 0.0 & 8.8 & 6.1 & 6.9 & 0.0 \\
\hline \multirow[t]{3}{*}{ Developing } & 5.2 & 2.0 & 9.7 & - & 0.0 & 2.8 & 15.4 & - \\
\hline & \multicolumn{4}{|c|}{ Twin Crisis (1980-97) } & \multicolumn{4}{|c|}{ Twin Crisis (1990-97) } \\
\hline & Peg & $\begin{array}{c}\text { Limited } \\
\text { Flexibility } \\
\end{array}$ & $\begin{array}{c}\text { Managed } \\
\text { Floating } \\
\end{array}$ & $\begin{array}{c}\text { Freely } \\
\text { Floating } \\
\end{array}$ & Peg & $\begin{array}{c}\text { Limited } \\
\text { Flexibility } \\
\end{array}$ & $\begin{array}{c}\text { Managed } \\
\text { Floating } \\
\end{array}$ & $\begin{array}{c}\text { Freely } \\
\text { Floating }\end{array}$ \\
\hline All & 1.6 & 1.4 & 0.8 & 0.0 & 3.2 & 2.6 & 0.0 & 0.0 \\
\hline Advanced & 0.0 & 0.7 & 0.0 & 0.0 & 0.0 & 2.2 & 0.0 & 0.0 \\
\hline Emerging & 7.7 & 3.0 & 1.8 & 0.0 & 15.4 & 4.0 & 0.0 & 0.0 \\
\hline Developing & 0.0 & 0.0 & 0.0 & - & 0.0 & 0.0 & 0.0 & - \\
\hline
\end{tabular}

Note: Probabilities are calculated by dividing the number of occurrences of a crisis under a particular regime by the total number of regime years. Each crisis is counted only once and hence, if it persists over multiple years, the subsequent years are not taken into account for this calculation. Additionally, the years an exchange rate regime transition takes place (i.e., the year preceding, the year during, and the year following the transition) are excluded from this computation. A dash (-) indicates that no crisis data were available for developing countries under freely floating exchange rate regimes.

Source: Authors' estimates. 
Table 8. Variable Description

\begin{tabular}{|c|c|c|}
\hline & Variable & Description \\
\hline IMF de jure regime dummies & $\begin{array}{l}\text { Pegged (de jure) } \\
\text { Intermediate (de jure) } \\
\text { Floating (de jure) }\end{array}$ & $\begin{array}{l}\text { Pegged regimes } \\
\text { Intermediate regimes } \\
\text { Floating regimes }\end{array}$ \\
\hline Natural regime dummies & $\begin{array}{l}\text { Pegged (natural) } \\
\text { Limited flexibility (natural) } \\
\text { Managed floating (natural) } \\
\text { Freely floating (natural) } \\
\text { Freely falling (natural) }\end{array}$ & $\begin{array}{l}\text { Pegged regimes (fine classification 1 4) } \\
\text { Limited flexibility regimes (fine classification 5 9) } \\
\text { Managed floating regimes (fine classification } 10 \sim 12 \text { ) } \\
\text { Freely floating regimes (fine classification 13) } \\
\text { Freely falling regimes (fine classification } 14 \text { ) }\end{array}$ \\
\hline Dependent Variable & & Control Variables \\
\hline $\begin{array}{l}\text { Inflation (scaled consumer } \\
\text { price inflation; } \mathrm{p} /(1+\mathrm{p}))\end{array}$ & $\begin{array}{l}\text { Money growth } \\
\text { Real GDP growth } \\
\text { Trade openness } \\
\text { Central bank turnover rate } \\
\text { Terms of trade growth } \\
\text { Government balance }\end{array}$ & $\begin{array}{l}\text { Broad money growth } \\
\text { Real GDP growth } \\
\text { Exports plus imports of goods and services (percent of GDP) } \\
\text { Central bank governor turnover rate (per } 5 \text { years) } \\
\text { Terms of trade growth } \\
\text { Central government balance (percent of GDP) }\end{array}$ \\
\hline Per capita real GDP growth & $\begin{array}{l}\text { Investment ratio } \\
\text { Trade openness } \\
\text { Terms of trade growth } \\
\text { Average years of schooling } \\
\text { Tax ratio } \\
\text { Government balance } \\
\text { Initial income/U.S. income } \\
\text { Population growth } \\
\text { Population size }\end{array}$ & $\begin{array}{l}\text { Gross fixed investment (percent of GDP) } \\
\text { Exports plus imports of goods and services (percent of GDP) } \\
\text { Terms of trade growth, } 3 \text { year backward average } \\
\text { Average number of years of schooling of total population age } 25 \text { and older (per } 5 \text { years) } \\
\text { General government revenue (percent of GDP), } 3 \text { year backward average } \\
\text { Central government balance (percent of GDP), } 3 \text { year backward average } \\
\text { Ratio of per capita GDP to U.S. per capita GDP in } 1970 \text { (international prices) } \\
\text { Population growth, } 3 \text { year backward average } \\
\text { Population (logarithm) }\end{array}$ \\
\hline & & Crisis Variables \\
\hline & $\begin{array}{l}\text { Bank crisis } \\
\text { Balance of payments crisis }\end{array}$ & $\begin{array}{l}\text { From Demirguc-Kunt and Detragiache (1997) } \\
\text { From Berg, Borensztein and Pattillo (2004) }\end{array}$ \\
\hline
\end{tabular}


Table 9. Inflation Performance Across Country Groups

\begin{tabular}{|c|c|c|c|c|c|c|c|c|c|}
\hline & \multicolumn{3}{|c|}{ Advanced Countries } & \multicolumn{3}{|c|}{ Emerging Markets } & \multicolumn{3}{|c|}{ Developing Countries } \\
\hline & $\begin{array}{c}\text { Country fixed } \\
\text { effects }\end{array}$ & $\begin{array}{l}\text { No country } \\
\text { fixed effects }\end{array}$ & $\begin{array}{l}\text { Country fixed } \\
\text { effects with two- } \\
\text { year lagged } \\
\text { regime variables }\end{array}$ & $\begin{array}{l}\text { Country fixed } \\
\text { effects }\end{array}$ & $\begin{array}{l}\text { No country } \\
\text { fixed effects }\end{array}$ & $\begin{array}{l}\text { Country fixed } \\
\text { effects with two- } \\
\text { year lagged } \\
\text { regime variables }\end{array}$ & $\begin{array}{c}\text { Country fixed } \\
\text { effects }\end{array}$ & $\begin{array}{l}\text { No country } \\
\text { fixed effects }\end{array}$ & $\begin{array}{l}\text { Country fixed } \\
\text { effects with two- } \\
\text { year lagged } \\
\text { regime variables }\end{array}$ \\
\hline Limited flexibility & $\begin{array}{l}-0.006 \\
(-1.38)\end{array}$ & $\begin{array}{c}0.007 \\
(2.10)^{* *}\end{array}$ & $\begin{array}{l}-0.005 \\
(-1.31)\end{array}$ & $\begin{array}{l}-0.027 \\
(-1.45)\end{array}$ & $\begin{array}{c}-0.029 \\
(-1.86)^{*}\end{array}$ & $\begin{array}{l}-0.020 \\
(-1.28)\end{array}$ & $\begin{array}{l}0.025 \\
(1.57)\end{array}$ & $\begin{array}{c}0.020 \\
(2.34)^{* *}\end{array}$ & $\begin{array}{c}0.027 \\
(1.96)^{* *}\end{array}$ \\
\hline Managed floating & $\begin{array}{l}-0.011 \\
(-1.71)^{*}\end{array}$ & $\begin{array}{l}0.007 \\
(1.42)\end{array}$ & $\begin{array}{l}-0.009 \\
(-1.33)\end{array}$ & $\begin{array}{l}-0.027 \\
(-1.40)\end{array}$ & $\begin{array}{l}0.006 \\
(0.41)\end{array}$ & $\begin{array}{l}0.023 \\
(1.64)\end{array}$ & $\begin{array}{l}0.022 \\
(1.27)\end{array}$ & $\begin{array}{c}0.023 \\
(2.85)^{* * *}\end{array}$ & $\begin{array}{c}0.037 \\
(2.86)^{* * *}\end{array}$ \\
\hline Freely floating & $\begin{array}{c}-0.015 \\
(-2.28)^{* *}\end{array}$ & $\begin{array}{c}-0.020 \\
(-4.81)^{* * *}\end{array}$ & $\begin{array}{c}-0.013 \\
(-1.89)^{*}\end{array}$ & $\begin{array}{l}-0.012 \\
(-0.36)\end{array}$ & $\begin{array}{l}-0.010 \\
(-0.42)\end{array}$ & $\begin{array}{c}0.059 \\
(2.16)^{* *}\end{array}$ & $\begin{array}{c}0.104 \\
(3.83)^{* * *}\end{array}$ & $\begin{array}{c}0.091 \\
(3.87)^{* * *}\end{array}$ & $\begin{array}{c}0.065 \\
(2.65)^{* * *}\end{array}$ \\
\hline Freely falling & $\begin{array}{c}0.225 \\
(5.90)^{* * *}\end{array}$ & $\begin{array}{c}0.302 \\
(7.10)^{* * *}\end{array}$ & $\begin{array}{c}0.141 \\
(5.60)^{* * *}\end{array}$ & $\begin{array}{c}0.234 \\
(7.61)^{* * *}\end{array}$ & $\begin{array}{c}0.322 \\
(13.18)^{* * *}\end{array}$ & $\begin{array}{c}0.244 \\
(9.04)^{* * *}\end{array}$ & $\begin{array}{c}0.232 \\
(10.80)^{* * *}\end{array}$ & $\begin{array}{c}0.288 \\
(16.73)^{* * *}\end{array}$ & $\begin{array}{c}0.149 \\
(7.50)^{* * *}\end{array}$ \\
\hline Money growth & $\begin{array}{c}0.698 \\
(2.44)^{* *}\end{array}$ & $\begin{array}{c}0.285 \\
(17.12)^{* * *}\end{array}$ & $\begin{array}{c}0.085 \\
(5.14)^{* * *}\end{array}$ & $\begin{array}{l}-0.032 \\
(-0.31)\end{array}$ & $\begin{array}{l}-0.097 \\
(-1.02)\end{array}$ & $\begin{array}{l}-0.011 \\
(-0.10)\end{array}$ & $\begin{array}{l}0.010 \\
(1.14)\end{array}$ & $\begin{array}{l}0.015 \\
(0.97)\end{array}$ & $\begin{array}{l}0.011 \\
(1.14)\end{array}$ \\
\hline Real GDP growth & $\begin{array}{l}-0.084 \\
(-0.46)\end{array}$ & $\begin{array}{l}-0.114 \\
(-0.47)\end{array}$ & $\begin{array}{c}0.354 \\
(3.15)^{* * * *}\end{array}$ & $\begin{array}{c}-1.498 \\
(-2.13)^{* *}\end{array}$ & $\begin{array}{c}-2.025 \\
(-2.90) * * *\end{array}$ & $\begin{array}{c}-1.656 \\
(-2.12)^{* *}\end{array}$ & $\begin{array}{l}-0.442 \\
(-1.58)\end{array}$ & $\begin{array}{c}-0.874 \\
(-1.82)^{*}\end{array}$ & $\begin{array}{c}-0.640 \\
(-1.69)^{*}\end{array}$ \\
\hline Trade openness & $\begin{array}{l}0.000 \\
(0.01)\end{array}$ & $\begin{array}{c}-0.006 \\
(-2.04)^{* *}\end{array}$ & $\begin{array}{c}-0.024 \\
(-2.28)^{* *}\end{array}$ & $\begin{array}{l}-0.008 \\
(-1.20)\end{array}$ & $\begin{array}{l}-0.008 \\
(-1.04)\end{array}$ & $\begin{array}{l}-0.003 \\
(-0.99)\end{array}$ & $\begin{array}{c}-0.032 \\
(-2.70)^{* * *}\end{array}$ & $\begin{array}{l}-0.012 \\
(-1.59)\end{array}$ & $\begin{array}{c}-0.033 \\
(-2.87)^{* * *}\end{array}$ \\
\hline Central bank turnover rate & $\begin{array}{l}0.009 \\
(0.69)\end{array}$ & $\begin{array}{c}0.020 \\
(2.10)^{* *}\end{array}$ & $\begin{array}{l}-0.014 \\
(-1.28)\end{array}$ & $\begin{array}{c}0.094 \\
(2.60)^{* * * *}\end{array}$ & $\begin{array}{c}0.152 \\
(4.76)^{* * * *}\end{array}$ & $\begin{array}{c}0.148 \\
(4.32)^{* * *}\end{array}$ & $\begin{array}{c}0.044 \\
(3.44)^{* * * *}\end{array}$ & $\begin{array}{c}0.022 \\
(1.66)^{*}\end{array}$ & $\begin{array}{c}0.063 \\
(4.39)^{* * * *}\end{array}$ \\
\hline Terms of trade growth & $\begin{array}{l}0.013 \\
(1.10)\end{array}$ & $\begin{array}{l}0.027 \\
(1.86)^{*}\end{array}$ & $\begin{array}{l}0.003 \\
(0.25)\end{array}$ & $\begin{array}{l}-0.031 \\
(-0.79)\end{array}$ & $\begin{array}{l}-0.035 \\
(-0.83)\end{array}$ & $\begin{array}{l}-0.037 \\
(-0.87)\end{array}$ & $\begin{array}{l}-0.001 \\
(-0.06)\end{array}$ & $\begin{array}{l}-0.008 \\
(-0.45)\end{array}$ & $\begin{array}{l}-0.009 \\
(-0.49)\end{array}$ \\
\hline Government balance & $\begin{array}{l}-0.038 \\
(-0.51)\end{array}$ & $\begin{array}{c}-0.116 \\
(-2.02)^{* *}\end{array}$ & $\begin{array}{l}-0.033 \\
(-0.56)\end{array}$ & $\begin{array}{c}-0.557 \\
(-3.74)^{* * *}\end{array}$ & $\begin{array}{l}-0.175 \\
(-1.64)\end{array}$ & $\begin{array}{c}-0.677 \\
(-4.75)^{* * *}\end{array}$ & $\begin{array}{c}-0.210 \\
(-2.77)^{* * *}\end{array}$ & $\begin{array}{c}-0.221 \\
(-2.57)^{* *}\end{array}$ & $\begin{array}{c}-0.324 \\
(-3.63)^{* * *}\end{array}$ \\
\hline Constant & $\begin{array}{l}-0.018 \\
(-0.31)\end{array}$ & $\begin{array}{c}0.072 \\
(6.27)^{* * *}\end{array}$ & $\begin{array}{c}-0.446 \\
(-9.22)^{* * *}\end{array}$ & $\begin{array}{l}0.370 \\
(1.01)\end{array}$ & $\begin{array}{l}0.445 \\
(1.35)\end{array}$ & $\begin{array}{l}0.249 \\
(0.62)\end{array}$ & $\begin{array}{c}0.336 \\
(3.63)^{* * *}\end{array}$ & $\begin{array}{c}0.069 \\
(2.49)^{* *}\end{array}$ & $\begin{array}{c}0.341 \\
(2.30)^{* *}\end{array}$ \\
\hline Observations & 673 & 673 & 673 & 617 & 617 & 617 & 1401 & 1401 & 1401 \\
\hline R-squared & 0.82 & 0.73 & 0.84 & 0.73 & 0.68 & 0.71 & 0.67 & 0.44 & 0.57 \\
\hline
\end{tabular}

Note: Figures in parentheses are t-statistics; * significant at 10 percent; ${ }^{* *}$ significant at 5 percent; *** significant at 1 percent.

Kuwait has been dropped as discussed in the text. 
Table 10. Growth Performance Across Country Groups

\begin{tabular}{|c|c|c|c|c|c|c|c|c|c|}
\hline & \multicolumn{3}{|c|}{ " Advanced Countries } & \multicolumn{3}{|c|}{ Emerging Markets } & \multicolumn{3}{|c|}{ Developing Countries } \\
\hline & $\begin{array}{l}\text { Country fixed } \\
\text { effects }\end{array}$ & $\begin{array}{c}\text { No country fixed } \\
\text { effects }\end{array}$ & $\begin{array}{l}\text { Country fixed } \\
\text { effects with two- } \\
\text { year lagged regime } \\
\text { variables }\end{array}$ & $\begin{array}{l}\text { Country fixed } \\
\text { effects }\end{array}$ & $\begin{array}{c}\text { No country fixed } \\
\text { effects }\end{array}$ & $\begin{array}{c}\text { Country fixed } \\
\text { effects with two- } \\
\text { year lagged regime } \\
\text { variables }\end{array}$ & $\begin{array}{l}\text { Country fixed } \\
\text { effects }\end{array}$ & $\begin{array}{c}\text { No country fixed } \\
\text { effects }\end{array}$ & $\begin{array}{c}\text { Country fixed } \\
\text { effects with two- } \\
\text { year lagged regime } \\
\text { variables }\end{array}$ \\
\hline Limited flexibility & $\begin{array}{l}0.004 \\
(1.04)\end{array}$ & $\begin{array}{l}0.003 \\
(1.11)\end{array}$ & $\begin{array}{c}0.010 \\
(2.09)^{* *}\end{array}$ & $\begin{array}{l}0.003 \\
(0.34)\end{array}$ & $\begin{array}{l}0.004 \\
(0.57)\end{array}$ & $\begin{array}{l}-0.007 \\
(-0.56)\end{array}$ & $\begin{array}{l}-0.005 \\
(-0.71)\end{array}$ & $\begin{array}{c}0.014 \\
(3.54)^{* * *}\end{array}$ & $\begin{array}{l}0.006 \\
(0.79)\end{array}$ \\
\hline Managed floating & $\begin{array}{c}0.008 \\
(1.65)^{*}\end{array}$ & $\begin{array}{l}0.004 \\
(1.29)\end{array}$ & $\begin{array}{c}0.013 \\
(2.47)^{* *}\end{array}$ & $\begin{array}{l}0.020 \\
(1.52)\end{array}$ & $\begin{array}{l}0.010 \\
(1.12)\end{array}$ & $\begin{array}{l}0.002 \\
(0.19)\end{array}$ & $\begin{array}{l}-0.008 \\
(-1.28)\end{array}$ & $\begin{array}{c}0.010 \\
(2.42)^{* *}\end{array}$ & $\begin{array}{l}-0.005 \\
(-0.86)\end{array}$ \\
\hline Freely floating & $\begin{array}{c}0.021 \\
(2.67)^{* * *}\end{array}$ & $\begin{array}{c}0.020 \\
(2.92)^{* * *}\end{array}$ & $\begin{array}{c}0.018 \\
(2.13)^{* *}\end{array}$ & $\begin{array}{l}-0.025 \\
(-0.88)\end{array}$ & $\begin{array}{l}-0.015 \\
(-0.85)\end{array}$ & $\begin{array}{l}-0.020 \\
(-0.47)\end{array}$ & $\begin{array}{l}-0.017 \\
(-1.03)\end{array}$ & $\begin{array}{l}-0.006 \\
(-0.43)\end{array}$ & $\begin{array}{l}0.002 \\
(0.15)\end{array}$ \\
\hline Freely falling & $\begin{array}{l}-0.005 \\
(-0.27)\end{array}$ & $\begin{array}{l}-0.006 \\
(-0.28)\end{array}$ & $\begin{array}{c}0.020 \\
(1.79)^{*}\end{array}$ & $\begin{array}{c}-0.045 \\
(-3.96)^{* * *}\end{array}$ & $\begin{array}{c}-0.035 \\
(-4.06)^{* * *}\end{array}$ & $\begin{array}{l}-0.023 \\
(-1.24)\end{array}$ & $\begin{array}{c}-0.032 \\
(-4.29)^{* * *}\end{array}$ & $\begin{array}{c}-0.019 \\
(-3.21)^{* * *}\end{array}$ & $\begin{array}{l}-0.002 \\
(-0.31)\end{array}$ \\
\hline Investment ratio & $\begin{array}{c}-0.180 \\
(-2.74)^{* * *}\end{array}$ & $\begin{array}{l}-0.092 \\
(-1.90)^{*}\end{array}$ & $\begin{array}{c}-0.230 \\
(-3.78)^{* * *}\end{array}$ & $\begin{array}{l}-0.048 \\
(-0.51)\end{array}$ & $\begin{array}{l}0.062 \\
(0.76)\end{array}$ & $\begin{array}{l}-0.037 \\
(-0.37)\end{array}$ & $\begin{array}{l}-0.033 \\
(-0.79)\end{array}$ & $\begin{array}{l}0.039 \\
(1.41)\end{array}$ & $\begin{array}{l}-0.025 \\
(-0.58)\end{array}$ \\
\hline Trade openness & $\begin{array}{c}0.037 \\
(2.51)^{* *}\end{array}$ & $\begin{array}{c}0.015 \\
(6.15)^{* * *}\end{array}$ & $\begin{array}{c}0.043 \\
(2.99)^{* * *}\end{array}$ & $\begin{array}{l}-0.006 \\
(-0.19)\end{array}$ & $\begin{array}{l}-0.006 \\
(-0.32)\end{array}$ & $\begin{array}{l}-0.013 \\
(-0.35)\end{array}$ & $\begin{array}{l}0.009 \\
(0.73)\end{array}$ & $\begin{array}{c}0.016 \\
(2.39)^{* *}\end{array}$ & $\begin{array}{l}0.006 \\
(0.43)\end{array}$ \\
\hline Terms of trade growth & $\begin{array}{l}0.056 \\
(1.64)\end{array}$ & $\begin{array}{l}0.011 \\
(0.36)\end{array}$ & $\begin{array}{c}0.060 \\
(1.77)^{*}\end{array}$ & $\begin{array}{l}0.011 \\
(0.32)\end{array}$ & $\begin{array}{l}0.001 \\
(0.03)\end{array}$ & $\begin{array}{l}0.036 \\
(0.93)\end{array}$ & $\begin{array}{l}-0.004 \\
(-0.21)\end{array}$ & $\begin{array}{l}0.019 \\
(0.98)\end{array}$ & $\begin{array}{l}-0.006 \\
(-0.31)\end{array}$ \\
\hline Average years of schooling & $\begin{array}{c}0.000 \\
(-0.02)\end{array}$ & $\begin{array}{l}-0.001 \\
(-0.88)\end{array}$ & $\begin{array}{l}0.000 \\
(0.02)\end{array}$ & $\begin{array}{l}0.017 \\
(1.22)\end{array}$ & $\begin{array}{l}0.005 \\
(1.33)\end{array}$ & $\begin{array}{l}0.015 \\
(1.06)\end{array}$ & $\begin{array}{c}-0.010 \\
(-2.02)^{* *}\end{array}$ & $\begin{array}{l}0.001 \\
(0.77)\end{array}$ & $\begin{array}{c}-0.014 \\
(-2.71)^{* * *}\end{array}$ \\
\hline Tax ratio & $\begin{array}{l}0.029 \\
(0.84)\end{array}$ & $\begin{array}{l}0.007 \\
(0.39)\end{array}$ & $\begin{array}{l}-0.010 \\
(-0.30)\end{array}$ & $\begin{array}{l}-0.047 \\
(-1.02)\end{array}$ & $\begin{array}{l}-0.010 \\
(-0.30)\end{array}$ & $\begin{array}{l}-0.029 \\
(-0.65)\end{array}$ & $\begin{array}{l}-0.011 \\
(-0.84)\end{array}$ & $\begin{array}{c}-0.028 \\
(-2.78)^{* * *}\end{array}$ & $\begin{array}{l}-0.013 \\
(-0.94)\end{array}$ \\
\hline Government balance & $\begin{array}{c}-0.102 \\
(-2.21)^{* *}\end{array}$ & $\begin{array}{c}-0.065 \\
(-2.08)^{* *}\end{array}$ & $\begin{array}{c}-0.117 \\
(-2.62)^{* * *}\end{array}$ & $\begin{array}{c}-0.277 \\
(-3.37)^{* * *}\end{array}$ & $\begin{array}{l}-0.086 \\
(-1.34)\end{array}$ & $\begin{array}{c}-0.233 \\
(-2.75)^{* * *}\end{array}$ & $\begin{array}{c}0.070 \\
(1.77)^{*}\end{array}$ & $\begin{array}{l}0.046 \\
(1.62)\end{array}$ & $\begin{array}{c}0.073 \\
(1.78)^{*}\end{array}$ \\
\hline Initial income/U.S. income & $\begin{array}{c}0.041 \\
(1.87)^{*}\end{array}$ & $\begin{array}{c}-0.021 \\
(-2.50)^{* *}\end{array}$ & $\begin{array}{c}0.043 \\
(2.00)^{* *}\end{array}$ & $\begin{array}{c}-0.285 \\
(-2.00)^{* *}\end{array}$ & $\begin{array}{c}-0.059 \\
(-2.30)^{* *}\end{array}$ & $\begin{array}{c}-0.191 \\
(-1.67)^{*}\end{array}$ & $\begin{array}{l}-0.022 \\
(-0.41)\end{array}$ & $\begin{array}{c}-0.034 \\
(-3.11)^{* * *}\end{array}$ & $\begin{array}{l}0.015 \\
(0.27)\end{array}$ \\
\hline Population growth & $\begin{array}{l}0.123 \\
(0.23)\end{array}$ & $\begin{array}{l}0.016 \\
(0.07)\end{array}$ & $\begin{array}{l}0.386 \\
(0.73)\end{array}$ & $\begin{array}{l}-0.196 \\
(-0.35)\end{array}$ & $\begin{array}{l}0.144 \\
(0.41)\end{array}$ & $\begin{array}{l}-0.255 \\
(-0.44)\end{array}$ & $\begin{array}{c}-0.679 \\
(-1.95)^{*}\end{array}$ & $\begin{array}{c}-0.432 \\
(-2.08)^{* *}\end{array}$ & $\begin{array}{c}-0.680 \\
(-1.88)^{*}\end{array}$ \\
\hline Population size & $\begin{array}{c}-0.133 \\
(-3.08)^{* * *}\end{array}$ & $\begin{array}{l}-0.001 \\
(-0.70)\end{array}$ & $\begin{array}{c}-0.140 \\
(-3.12)^{* * *}\end{array}$ & $\begin{array}{l}0.029 \\
(0.94)\end{array}$ & $\begin{array}{l}0.003 \\
(0.89)\end{array}$ & $\begin{array}{l}0.034 \\
(0.90)\end{array}$ & $\begin{array}{l}-0.020 \\
(-0.84)\end{array}$ & $\begin{array}{l}0.002 \\
(0.83)\end{array}$ & $\begin{array}{l}-0.003 \\
(-0.11)\end{array}$ \\
\hline Constant & $\begin{array}{c}-0.176 \\
(-1.98)^{* *}\end{array}$ & $\begin{array}{c}0.072 \\
(3.18)^{* * *}\end{array}$ & $\begin{array}{l}-0.173 \\
(-1.96)^{*}\end{array}$ & $\begin{array}{l}-0.032 \\
(-0.27)\end{array}$ & $\begin{array}{l}-0.003 \\
(-0.12)\end{array}$ & $\begin{array}{l}-0.074 \\
(-0.55)\end{array}$ & $\begin{array}{l}0.101 \\
(1.20)\end{array}$ & $\begin{array}{c}0.030 \\
(2.27)^{* *}\end{array}$ & $\begin{array}{l}0.070 \\
(0.76)\end{array}$ \\
\hline Observations & 605 & 605 & 596 & 529 & 529 & 520 & 1228 & 1228 & 1209 \\
\hline R-squared & 0.38 & 0.32 & 0.41 & 0.30 & 0.20 & 0.23 & 0.25 & 0.15 & 0.23 \\
\hline
\end{tabular}

Note: Figures in parentheses are t-statistics; * significant at 10 percent; ** significant at 5 percent; $* * *$ significant at 1 percent.

Kuwait has been dropped as discussed in the text. 